\title{
The Drivers of National System of Innovation in Portugal: A Panel Data Analysis
}

\author{
Marcelo Duarte ${ }^{1 *}$, Fernando Carvalho ${ }^{1}$
}

${ }^{1}$ University of Coimbra, CeBER, Faculty of Economics, PORTUGAL

*Corresponding Author: mpd@fe.uc.pt

Citation: Duarte, M. and Carvalho, F. (2020). The Drivers of National System of Innovation in Portugal: A Panel Data Analysis. Journal of Information Systems Engineering and Management, 5(2), em0114. https://doi.org/10.29333/jisem/8248

ARTICLE INFO

Published: 15 May. 2020

\begin{abstract}
The growing awareness of the importance of national systems of innovation on countries' development led to an increased availability of instruments designed to measure and compare the innovative capacity of countries. Such instruments provide policymakers with a panoply of relevant information, with which they can stimulate innovation within their territory, thereby increasing national competitiveness. Among the most used innovation indices, the Global Innovation Index (GII) stands out by explicitly distinguishing innovation inputs and outputs, hence, drawing from its input-output framework and extant literature on innovation, we intend to answer the question: Which innovation inputs are more strongly related to innovative outputs? Thus, deriving policy implications aimed at improving Portugal's innovative readiness. To answer this question, and due to the crosssectional nature of the GII, we have developed our own panel dataset version composed by 92 countries in the period 2013-2018, which we then analyse through a series of multiple regression techniques, emphasising the results of Eurozone countries and comparing Portugal to them. Results suggest a strong, positive influence of Business Sophistication on innovation outputs in Eurozone countries, derived mainly from the capacity of domestic firms to absorb knowledge. Possible policy implications are derived from this fact, such as, for instance, an encouragement to inward foreign direct investment. However, further research is needed to analyse the differentiated effects of such encouragement, as well as for other surprising results of our study.
\end{abstract}

Keywords: innovation, global innovation index, innovation inputs, innovation outputs, panel data, Portugal

\section{INTRODUCTION}

National Systems of Innovation (NSI) are recognised as cornerstones for countries' development and international competitiveness (Fagerberg and Srholec, 2008; Freeman, 1987, 1995; Furman et al., 2002; Lundvall, 1992; Nelson, 1993), being recognised by the United Nations as part of one Sustainable Development Goal (SDG, UN, 2015). Edquist (2006: 182) defined NSI as

"all important economic, social, political, organisational, institutional, and other factors that influence the development, diffusion, and use of innovations",

which highlights the essentially systemic nature of innovation, involving both organisations and state in the innovation process within a nation. In order to improve a country's innovative capacities, policy decisionmakers must be able to understand which factors are driving innovation within their economies (Kuhlman et al., 2017). Following the you cannot manage what you cannot measure rationale, it becomes necessary to find ways of measuring the investment made in NSI and the resulting outcomes of such investments (Borrás and Laatsit, 2019). In fact, Archibugi et al. (2009) argues that there are at least three reasons that justify a systematic collection of innovation data. First, from a theoretical standpoint it allows academics to test innovation theories, since innovation has been considered a determinant of economic growth, employment, productivity, and competitiveness (Fagerberg and Srholec, 2008; Porter and Stern, 1999). Second, NSI measures allow policy decision makers to identify national strengths and weaknesses by comparison with other countries, as well as assessing the effectiveness of adopted policies. Third, they are extremely useful for business strategies, particularly as an aid to decision making regarding localisation of innovative activities along a company's global value chain (Khan \& Yu, 2019). To that end, several authors and major international organisations have developed frameworks to analyse the innovation readiness of countries, such as Porter and Stern (1999), Innovation Agency (ANI) in the call "R\&D and Innovation in the Digital Economy" 
Archibugi and Coco (2004), the European Innovation Scoreboard (European Comission, 2018), the OECD Science, Technology and Industry Scoreboard (STI, OECD, 2017), or the Global Innovation Index (GII, Cornell University et al., 2018).

These composite indicators are rather common in empirical research (Archibugi et al., 2009), having been used as tools to conduct case studies (Alfantookh and Bakry, 2015; Erciş and Ünalan, 2016; Iqbal, 2011; Marxt and Brunner, 2013), to rank countries according to their innovative capacity (Barragán-Ocaña et al., 2020; Edquist et al., 2018; Pençe et al., 2019), to assess ideal configurational conditions of NSI (Crespo and Crespo, 2016; Khedhaouria and Thurik, 2017), or to analyse the relationships between the various NSI dimensions (Nasierowski and Arcelus, 1999; Sohn et al., 2016). However, although some empirical studies consider an input-output framework (Crespo and Crespo, 2016; Edquist et al., 2018; Khedhaouria and Thurik, 2017; Nasierowski and Arcelus, 1999; Sohn et al., 2016), very few adopt a longitudinal perspective, considering at best a comparison between two consecutive years (Edquist et al., 2018; Zabala-Iturriagagoitia et al., 2007). The use of a cross-sectional perspective renders a static picture of the relationships between NSI dimensions in a given moment, thus failing to find evidence of the medium- long-term impact of innovation inputs on innovative outputs. Therefore, to address this gap, we analyse the relationships between innovation inputs and outputs, while controlling for the effects of time. Drawing from the input-output framework (Godin, 2007), we intend to answer the question: Which innovation inputs are more strongly related to innovative outputs? Thus, deriving policy implications aimed at improving Portugal's innovative readiness. To answer it, we rely on the framework provided by the GII due to its clear distinction between innovation inputs and outputs, based on more than 80 comparable indicators (Cornell University et al., 2018). The index, besides being developed by major international organisations, is audited by European Commission's Joint Research Centre to attest its statistical validity. Therefore, it may be used as a leading reference for policymakers, business executives, as well as for researchers (Archibugi et al., 2009; Sohn et al., 2016). Nonetheless, the GII methodology gives rise to a number of difficulties if one aims to compare countries' scores over time (Cornell University et al., 2018). The major concern in this respect is that reports are conducted to assess innovation readiness of countries in a given year, lacking a longitudinal framework to track changes over time. One of the GIl's aims is to include as many middle- and low-economies as possible, which, depending on the availability of data, results in different sample sizes throughout the years. To address this, and other methodological limitations of the GII, we have developed our own panel dataset version of the GII by following its methodology, to the extent possible, resulting in a set of 92 countries for six years (2013-2018). Our hypotheses are then tested by means of multiple regression analyses, in order to understand which inputs have a greater contribution to innovative outputs. Furthermore, we narrowed the analyses, focusing exclusively on a group of countries that, besides being subjected to similar innovation regulations and demands as Portugal, also share a deeper European integration in terms of currency, the Eurozone, which allowed us to make meaningful comparisons with Portugal.

The remainder of this paper is structured as follows. In section 2, we make a brief description of the GII, its components, methodology and limitations, followed, in section 3, with a development of our own panel dataset version of the GII. Next, in section 4, we elaborate on Portugal's performance over time and compare it with the Eurozone average. In section 5, we propose a conceptual model to answer the research question and, following the literature review, we propose the hypothesis. The methodology used constitutes section 6 . In section 7 , results are presented and discussed, as well as the development of policy implications for Portugal. Lastly, section 8 concludes, including the study's limitations and directions for future research.

\section{THE GLOBAL INNOVATION INDEX (GII)}

As mentioned before, we make use of the GIl framework to analyse which innovation inputs are more strongly related to innovative outputs. The GII was launched in 2007 by INSEAD to shed light on the measurement of innovation readiness of countries and to find means of generating meaningful comparisons (Dutta et al., 2007), helping business leaders and public policymakers to understand the reasons of a nation's relative performance (Dutta, 2009).

The latest GII report (Cornell University et al., 2018) covers 126 countries, compared along 80 indicators ${ }^{1}$. Its framework relies on the distinction between inputs and outputs to measure innovation in an economy, being inputs the elements of the national economy that enable innovative activities, and outputs the results of innovative activities within the economy. Indicators are aggregated in a total of 21 sub-pillars ${ }^{2}$, which, in turn, are aggregated under seven pillars. Five of those are input pillars, consisting in Institutions, Human Capital and Research, Infrastructure, Market Sophistication, and Business Sophistication, while two are output pillar, namely Knowledge and Technology Outputs, and Creative Outputs. Both input and output pillars are then aggregated to form the Input and the Output sub-indices (Figure 1).

\footnotetext{
${ }^{1}$ The number of countries included in each report varies from one year to the next, and the same happens to the indicators used.

${ }^{2}$ Since 2013 , only one sub-pillar had its name changed. Trade, competition, and market scale was called Trade and competition until 2015.
} 


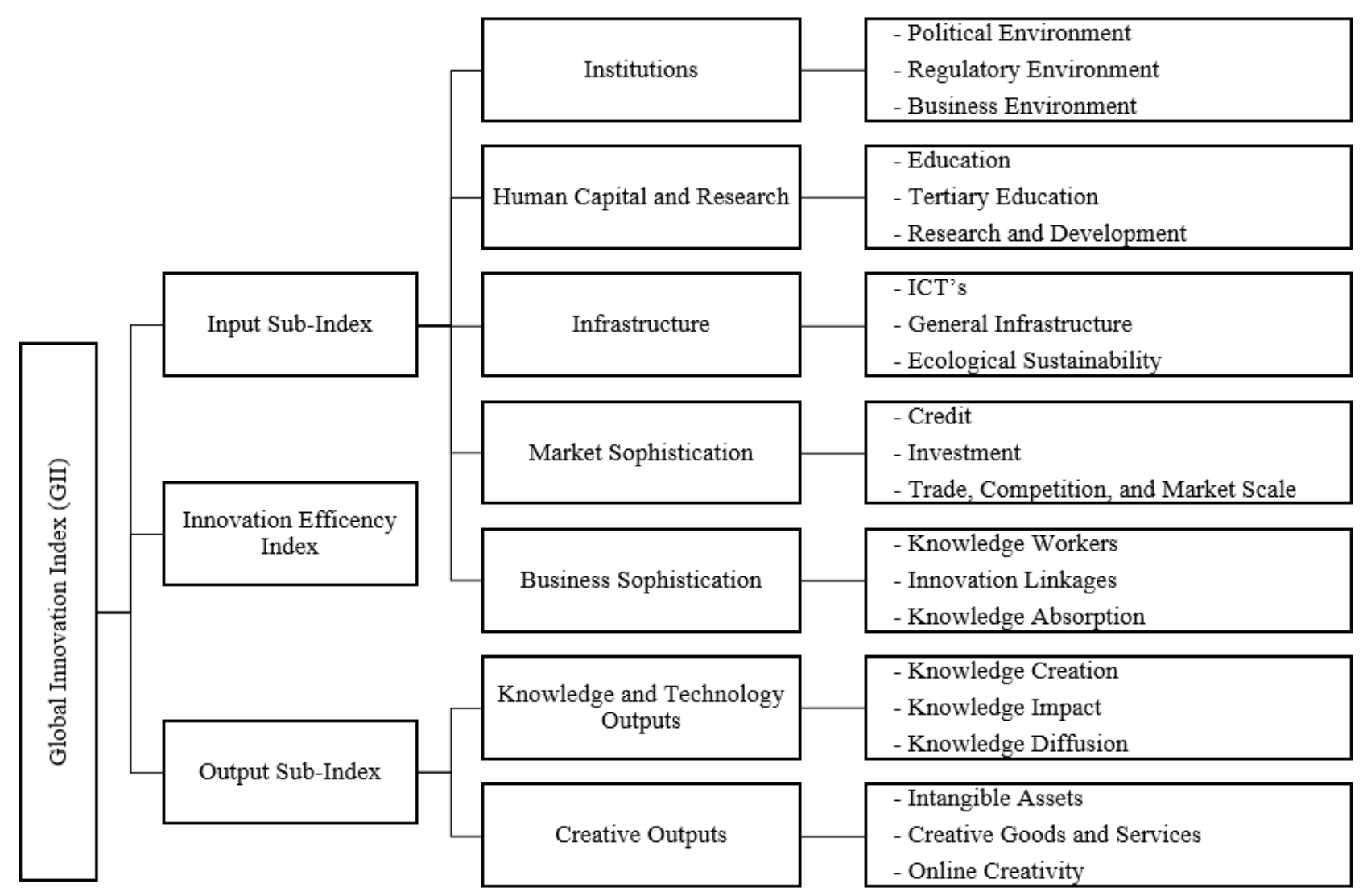

Figure 1. Global Innovation Index framework Source: Cornell University et al. (2018)

A weighted average of the normalised indicators forms the sub-pillars' scores, which, with another weighted average, form the pillars' scores. The input sub-index is obtained through a simple average of the five input pillars and output sub-index from a simple average of the two output pillars. The final GII results from the simple average of input and output sub-indices. The framework also includes an Innovation Efficiency Index, which is the ratio of the output sub-index over the input sub-index, showing how much innovation outputs a country is obtaining for its inputs.

The index relies on numerous sources of data, such as the World Intellectual Property Organization (WIPO), World Economic Forum's (WEF) Executive Opinion Survey, World Bank's Worldwide Governance Indicators and Doing Business, among many others. As such, the resulting data comes in three forms: hard data, composite indicators, and survey questions of WEF's Executive Opinion Survey. In order to make meaningful comparisons, the indicators are subjected to a normalisation process using a minmax method.

Nevertheless, the use of GII scores as panel data is discouraged due to several methodological issues (Cornell University et al., 2018). First, the GII is compiled on an annual basis, providing a cross-country innovation performance assessment, hence presenting the characteristics of a cross-sectional study (i.e., several individuals at one moment in time) rather than panel data (several individuals tracked through several periods of time). As such, methodological changes from one year to the next distort the results in a panel study. Second, since 2007, the framework has undergone several changes in its structure, with the addition or removal of pillars, sub-pillars, and individual indicators. Third, from one year to the next, several countries are added or removed, based on the availability of indicators. Fourth, indicators' collection over time suffer from changes in definitions and methodologies. Fifth, collected data undergoes a process of normalisation, thus rendering it incomparable in the presence of changes from one year to the next.

\section{PROPOSED PANEL DATASET VERSION OF THE GII}

To address the constraints expressed above, we took the following steps.

\section{Period Selection}

GII raw data is available in the website only since the 2013 report, hence we have considered the period from 2013 to 2018.

\section{Indicators Selection and Collection}

As mentioned above, some indicators were added or removed during the period of analysis. As such, aiming to maximise the total number of indicators, we have taken the following steps: (1) we dropped seven indicators which appeared only in 2013 and 2014 (Press freedom, Gross tertiary outbound enrolment, Electricity consumption, Market access for non-agricultural exports, 
GMAT mean scores, GMAT test takers, and Daily newspapers circulation), and one whose only appearance is in 2018 (Mobile app creation); (2) we have also dropped two indicators for which we had only three consecutive years of data, due to lack of availability of data at the original source (Global R\&D companies (average expenditure, top 3), and Patent families filled in at least two/three offices); (3) for two indicators, the last year was left blank due to a change in their collection methodology and lack of available data at the original source (High-tech and medium high-tech output, and Printing, publications and other media output). For the same reason, one indicator was left with the last two years blank (Wikipedia monthly edits) and one indicator was left with the first year blank (Entertainment and media market); (4) two other indicators were left with the last year blank due to their removal of the 2018 report (Ease of paying taxes, and Video uploads on YouTube). The complete list of indicators used, as well as their definitions, sources and time-series, is shown in Table A1 in Appendix.

\section{Country Selection}

Since the number of countries present in GII reports varies from one year to the next, we have first selected those which are present in every report in the period of 2013 to 2018. Next, following Cornell University et al. (2018), we dropped countries which had more than $33 \%$ of missing values of the 53 input indicators (average for the period), and more than $33 \%$ of missing values of the 27 output indicators (average for the period). As such, we have obtained a sample of 92 countries (Table A2 in Appendix) which, according to the World Bank's World Development Indicators, in 2017 accounted for $69.5 \%$ of the world GDP (PPP \$) and about $84.4 \%$ of the world's population.

\section{Identification and Treatment of Series with Outliers}

Following the same methodology used in the GII, we have identified a total of 35 indicators with outliers that could polarise results: 34 out of the 57 hard data indicators and 1 out of the 18 composite indicators. The identification and treatment of series with outliers was done through the following steps: (1) first, we have used the criterion of absolute skewness greater than 2.25, or a kurtosis greater than 3.5 to identify problematic indicators; (2) then, series with one to five outliers (indicator 212) were winsorised, where the values distorting the indicator were assigned the next highest value, up to where the previous criterion was met (only one value was adjusted, from 64.997 to 64); (3) series with more than five outliers were multiplied by a given factor $f$ (both positive and negative powers of 10 were used) and transformed into their natural logarithms according to the following formulas:

$$
\begin{array}{ll}
\text { for 'goods' indicators: } & \ln \left[\frac{(\max * f-1)(\text { economy value }-\min )}{\max -\min }+1\right] \\
\text { for 'bads' indicators: } & \ln \left[\frac{(\max * f-1)(\max -\text { economy value })}{\max -\min }+1\right]
\end{array}
$$

Where 'min' and 'max' are the minimum and maximum indicator sample values, and 'goods' and 'bads' are indicators for which higher values indicates better and worse outcomes, respectively. For indicators 534 and 634, although the log transformation did lower their skewness and kurtosis values, it was not sufficient to meet the criterion (skewness 2.28 and kurtosis 34.33 , and skewness 2.16 and kurtosis 43.21 , respectively), hence we have decided to keep the transformed indicators avoiding further transformations.

\section{Normalisation}

According to the methodology of the GIl, all 80 indicators were normalised into the $[0,100]$ range, with higher score representing better outcomes. We used the min-max method to normalise indicators, where the min and max values were given by the minimum and maximum indicator sample value respectively, except for survey data and some indices, for which original ranges were kept as minimum and maximum values $([-2.5,2.5]$ for the Worldwide Governance Indicators; $[1,7]$ for the World Economic Forum Executive Opinion Survey questions; [0, 100] for the QS World University Ranking; [0, 10] for the ITU indices; [0, 1] for the United Nations Public Administration Network indices; [1, 5] for the Logistics Performance Index; and [0, 100] for the Environmental Performance Index). Thus, we have applied the following formulas:

$$
\begin{array}{ll}
\text { 'Goods': } & \frac{\text { economy value }- \text { min }}{\max -\min } * 100 \\
\text { 'Bads': } & \frac{\max -\text { economy value }}{\max -\min } * 100
\end{array}
$$

\section{Aggregation and Indices Construction}

Normalised indicators were aggregated at the sub-pillar level via arithmetic average, which is rather common in the literature (Becker et al., 2018; Grupp and Schubert, 2010), with the weights proposed in Cornell University et al. (2018), namely 35 indicators were given a weight of 0.5 while the remaining 45 were given the weight of 1.0 . These weights were used as scaling coefficients and not as importance coefficients, with the objective of obtaining indicators that can explain a similar amount of variance in their respective sub-pillar. Pillars were then created by a simple average of their respective sub-pillars, and the input and output subindices were created by a simple average of their respective pillars. Lastly, the overall index was created by a simple average of input and output sub-indices, while the efficiency index is the ratio of the output sub-index over the input sub-index. 
Table 1. Top 10 ranking on the GII against the DuCa framework

\begin{tabular}{|c|c|c|c|c|c|c|c|c|c|c|c|c|}
\hline \multirow{2}{*}{ Rank } & \multicolumn{2}{|c|}{2013} & \multicolumn{2}{|c|}{2014} & \multicolumn{2}{|c|}{2015} & \multicolumn{2}{|c|}{2016} & \multicolumn{2}{|c|}{2017} & \multicolumn{2}{|c|}{2018} \\
\hline & GII & DuCa & GII & DuCa & GII & DuCa & GII & DuCa & GII & DuCa & GII & DuCa \\
\hline 1 & $\mathrm{CHE}$ & DNK & $\mathrm{CHE}$ & USA & $\mathrm{CHE}$ & NLD & $\mathrm{CHE}$ & NLD & $\mathrm{CHE}$ & $\mathrm{CHE}$ & $\mathrm{CHE}$ & NLD \\
\hline 2 & SWE & GBR & GBR & DNK & GBR & USA & SWE & USA & SWE & NLD & NLD & $\mathrm{CHE}$ \\
\hline 3 & GBR & USA & SWE & $\mathrm{IRL}$ & SWE & GBR & GBR & $\mathrm{CHE}$ & NLD & USA & SWE & GBR \\
\hline 4 & NLD & $\mathrm{IRL}$ & FIN & $\mathrm{CHE}$ & NLD & $\mathrm{CHE}$ & USA & GBR & USA & GBR & GBR & SWE \\
\hline 5 & USA & FIN & NLD & FIN & USA & $\mathrm{IRL}$ & FIN & SWE & GBR & SWE & SGP & DNK \\
\hline 6 & FIN & FRA & USA & DEU & FIN & DNK & SGP & FIN & DNK & DNK & USA & USA \\
\hline 7 & HKG & SWE & SGP & SWE & SGP & DEU & $\mathrm{IRL}$ & DNK & SGP & FIN & FIN & DEU \\
\hline 8 & SGP & NLD & DNK & GBR & IRL & SWE & DNK & DEU & FIN & DEU & DNK & FIN \\
\hline 9 & DNK & $\mathrm{CHE}$ & LUX & NLD & LUX & FIN & NLD & FRA & DEU & FRA & DEU & FRA \\
\hline 10 & $\mathrm{IRL}$ & DEU & HKG & KOR & DNK & FRA & DEU & KOR & IRL & KOR & $\mathrm{IRL}$ & KOR \\
\hline
\end{tabular}

Source: Cornell University et al. (2013, 2014, 2015, 2016, 2017, 2018) and own calculations.

Note: CHE - Switzerland; DEU - Germany; DNK - Denmark; FIN - Finland; FRA - France; GBR - United Kingdom; HKG - Hong Kong (China); IRL Ireland; KOR - Republic of Korea; LUX - Luxembourg; NLD - Netherlands; SGP - Singapore; SWE - Sweden; USA - United States of America.

Table 2. Mean scores and yearly means

\begin{tabular}{|c|c|c|c|c|c|c|c|}
\hline \multirow{2}{*}{ Variable } & \multirow{2}{*}{ Mean } & \multicolumn{6}{|c|}{ Yearly means } \\
\hline & & 2013 & 2014 & 2015 & 2016 & 2017 & 2018 \\
\hline Input sub-index & 35.08 & 34.04 & 34.33 & 34.93 & 35.52 & 36.29 & 35.35 \\
\hline Output sub-index & 28.16 & 30.13 & 28.86 & 28.93 & 27.82 & 26.52 & 26.68 \\
\hline GII & 31.62 & 32.09 & 31.60 & 31.93 & 31.67 & 31.40 & 31.01 \\
\hline Innovation Efficiency Index & 0.802 & 0.895 & 0.847 & 0.827 & 0.779 & 0.721 & 0.743 \\
\hline \multicolumn{8}{|l|}{ Input pillars: } \\
\hline Institutions & 50.62 & 49.24 & 49.41 & 51.05 & 51.60 & 51.47 & 50.97 \\
\hline Human Capital and Research & 25.41 & 25.50 & 24.85 & 25.82 & 25.74 & 25.83 & 24.71 \\
\hline Infrastructure & 41.68 & 36.78 & 38.11 & 40.73 & 43.39 & 45.99 & 45.09 \\
\hline Market Sophistication & 35.98 & 36.83 & 37.33 & 35.71 & 35.08 & 35.53 & 35.38 \\
\hline Business Sophistication & 21.69 & 21.87 & 21.95 & 21.36 & 21.77 & 22.61 & 20.58 \\
\hline \multicolumn{8}{|l|}{ Output pillars: } \\
\hline Knowledge and Technology Outputs & 19.42 & 19.82 & 19.49 & 19.42 & 19.72 & 19.84 & 18.23 \\
\hline Creative Outputs & 36.89 & 40.44 & 38.23 & 38.43 & 35.91 & 33.21 & 35.13 \\
\hline
\end{tabular}

Source: Own calculations.

The resulting dataset is composed by 92 countries along six years (2013-2018). Table 1 ranks the top 10 countries on the GII and compares it against the newly developed panel data version framework (DuCa). One particularly interesting fact is that Switzerland lose its ubiquitous first place to Denmark, United States of America, and Netherlands, with Netherlands achieving the first position in three of the six years studied. Also, in the DuCa framework, Hong Kong, Singapore and Luxembourg never reach the top 10, whereas Republic of Korea does, first appearing in the $10^{\text {th }}$ position in 2014 and maintains it from 2016 onwards.

Table 2 shows the mean values on the DuCa framework, both sub-indices, and the seven pillars, as well as their yearly means for the period 2013-2018. When looking at the output pillars, it can be seen that, on average, countries are far more productive in Creative Outputs than on Knowledge and Technology Outputs. Regarding inputs, Business Sophistication, followed by Human Capital and Research, are the less developed enablers of innovation, with Institutions and Infrastructure being the most developed, in average terms. Table 2 also reveals a negative trend of the overall index, with an increase in 2015. The Innovation Efficiency Index also decreases over time, although an improvement exists in the last year. This negative trend of innovation efficiency is due to both increases of inputs and decreases of outputs. Contrary to this overall negative trend, input pillars Institutions and Infrastructure revealed a positive evolution from 2013 to 2018.

From this point onwards, all analyses are based on the panel data version (DuCa) developed above. Nevertheless, the terms used will be those of the GII framework.

\section{PORTUGAL'S PERFORMANCE}

In this section, we describe Portugal's innovation performance over time and relative to Eurozone. Table 3 shows Portugal's overall ranking and scores down to the pillar level, revealing an overall ranking drop from the $29^{\text {th }}$ position in 2013 to the $30^{\text {th }}$ in 2018, notwithstanding climbs in $2014\left(27^{\text {th }}\right), 2015\left(25^{\text {th }}\right)$ and $2017\left(28^{\text {th }}\right)$. This shift in position is explained partially by Portugal's performance and partially by other countries' performance. For instance, we can observe a drop on Portugal's GII score from 2013 to 2014, and yet it raised two positions on the ranking. Table 3 also reveals some trends over time, at the pillar level, which are in line with the overall trends for the total sample. Almost all pillars present a deterioration from 2013 to 2018, with the exception being Institutions (+10.5\%) and Infrastructure (+21.8\%). The largest negative variations from 2013 to 2018 are Market Sophistication (-16.0\%), Human Capital and Research (-15.2\%), and Business Sophistication (-12.7\%). 
Table 3. Portugal's GII ranking and scores

\begin{tabular}{|c|c|c|c|c|c|c|c|}
\hline Variable & 2013 & 2014 & 2015 & 2016 & 2017 & 2018 & $\Delta 13-18$ \\
\hline Input sub-index & 39.83 & 40.76 & 42.13 & 41.23 & 41.61 & 39.63 & $-0.5 \%$ \\
\hline Output sub-index & 35.35 & 34.30 & 36.27 & 34.00 & 33.75 & 33.88 & $-4.2 \%$ \\
\hline GII score & 37.59 & 37.53 & 39.20 & 37.61 & 37.68 & 36.75 & $-2.2 \%$ \\
\hline GII ranking & 29 & 27 & 25 & 29 & 28 & 30 & -1 \\
\hline Innovation Efficiency Index & 0.887 & 0.842 & 0.861 & 0.825 & 0.811 & 0.855 & $-3.6 \%$ \\
\hline \multicolumn{8}{|l|}{ Input pillars: } \\
\hline $\begin{array}{l}\text { Institutions } \\
\end{array}$ & 54.54 & 57.32 & 60.66 & 60.44 & 61.42 & 60.24 & $10.5 \%$ \\
\hline Human Capital and Research & 37.25 & 36.89 & 37.89 & 37.21 & 36.37 & 31.60 & $-15.2 \%$ \\
\hline Infrastructure & 40.63 & 42.65 & 45.35 & 47.94 & 50.00 & 49.48 & $21.8 \%$ \\
\hline Market Sophistication & 43.16 & 43.28 & 42.25 & 37.66 & 37.01 & 36.25 & $-16.0 \%$ \\
\hline Business Sophistication & 23.55 & 23.64 & 24.47 & 22.87 & 23.24 & 20.56 & $-12.7 \%$ \\
\hline \multicolumn{8}{|l|}{ Output pillars: } \\
\hline Knowledge and Technology Outputs & 21.53 & 20.84 & 22.53 & 22.31 & 23.01 & 20.93 & $-2.8 \%$ \\
\hline Creative Outputs & 49.17 & 47.76 & 50.01 & 45.68 & 44.49 & 46.83 & $-4.8 \%$ \\
\hline
\end{tabular}

Source: Own calculations.

Table 4. Eurozone countries GII scores

\begin{tabular}{|c|c|c|c|c|c|c|c|}
\hline Country & 2013 & 2014 & 2015 & 2016 & 2017 & 2018 & $\Delta 13-18$ \\
\hline Austria & 42.24 & 42.05 & 42.47 & 41.99 & 42.00 & 41.49 & $-1.8 \%$ \\
\hline Belgium & 39.38 & 38.84 & 39.10 & 39.26 & 39.14 & 38.49 & $-2.3 \%$ \\
\hline Cyprus & 38.39 & 33.92 & 33.71 & 35.70 & 35.60 & 34.59 & $-9.9 \%$ \\
\hline Estonia & 39.26 & 38.30 & 39.70 & 39.21 & 39.02 & 37.71 & $-3.9 \%$ \\
\hline Finland & 45.33 & 45.21 & 44.96 & 45.33 & 45.06 & 42.93 & $-5.3 \%$ \\
\hline France & 45.09 & 44.45 & 44.93 & 44.36 & 43.95 & 42.54 & $-5.7 \%$ \\
\hline Germany & 44.16 & 45.18 & 45.47 & 44.43 & 44.48 & 44.10 & $-0.1 \%$ \\
\hline Greece & 32.83 & 33.08 & 35.07 & 33.79 & 32.82 & 32.79 & $-0.1 \%$ \\
\hline Ireland & 45.35 & 45.32 & 45.63 & 43.86 & 42.62 & 41.69 & $-8.1 \%$ \\
\hline Italy & 37.62 & 36.97 & 38.45 & 37.78 & 37.29 & 36.94 & $-1.8 \%$ \\
\hline Latvia & - & 35.00 & 36.39 & 36.92 & 36.71 & 34.57 & $-1.2 \%$ \\
\hline Lithuania & - & - & 34.57 & 34.35 & 33.90 & 33.28 & $-3.7 \%$ \\
\hline Luxembourg & 42.24 & 40.05 & 40.98 & 40.33 & 41.05 & 39.09 & $-7.5 \%$ \\
\hline Malta & 34.54 & 34.79 & 35.03 & 35.28 & 37.46 & 36.78 & $6.5 \%$ \\
\hline Netherlands & 44.54 & 44.76 & 47.32 & 47.54 & 46.70 & 46.53 & $4.5 \%$ \\
\hline Portugal & 37.59 & 37.53 & 39.20 & 37.61 & 37.68 & 36.75 & $-2.2 \%$ \\
\hline Slovakia & 33.31 & 32.82 & 34.04 & 33.34 & 33.25 & 32.50 & $-2.4 \%$ \\
\hline Slovenia & 39.03 & 38.17 & 38.63 & 37.87 & 37.89 & 37.57 & $-3.7 \%$ \\
\hline Spain & 40.06 & 39.94 & 40.47 & 39.15 & 38.86 & 38.23 & $-4.6 \%$ \\
\hline Eurozone Mean & 40.06 & 39.24 & 39.80 & 39.37 & 39.24 & 38.35 & $-4.3 \%$ \\
\hline
\end{tabular}

Source: Own calculations.

Note: Latvia and Lithuania only joined the Eurozone in 2014 and 2015, respectively, hence the lack of values for such years. The variation for Latvia is from 2014 to 2018, and for Lithuania from 2015 to 2018.

Table 4 present the overall scores of Eurozone countries on the DuCa framework, highlighting Portugal's scores and Eurozone mean. Overall, there is evidence of a decrease on the innovation index in the Eurozone, consistent with the tendency explored in the previous section (Table 2). However, some countries have evolved positively from 2013 to 2018, namely Malta (+6.5\%) and Netherlands (+4.5\%). As for Portugal, although a negative trend persists $(-2.2 \%)$, its decline was less pronounced than that of the Eurozone mean (-4.3\%).

Table 5 shows a comparison of Portugal's scores against Eurozone's and Eurozone Top 3 performers' means, down to the pillar level, revealing that Portugal has space for improvement regarding its innovation convergence with its monetary partners. In a first analysis, comparing with Eurozone, in terms of innovation efficiency, Portugal is very close to Eurozone mean, having surpassed it in the last two years of the study. Table $\mathbf{5}$ also reveals a positive gap, towards Portugal, in the Human Capital and Research pillar, although the country has been losing ground since 2014. Market Sophistication in Portugal has been deteriorating, comparatively with Eurozone mean, where a positive gap existed in the early years of the study, it became a negative one in the latter years. Also worthy of highlight, Portugal's largest gap towards Eurozone mean concerns Business Sophistication, which, in the last year, reached its peak (-23.8\%), revealing an area worthy of improvement. Besides Business Sophistication, Portugal also presents moderately large gaps, towards the Eurozone, in Knowledge and Technology Outputs (-8.2\% in 2018) and Infrastructure $(-6.0 \%$ in 2018).

Comparing Portugal to Eurozone Top 3 performers, Table 5 reveals that, in 2018, the larger gap was in the Business Sophistication pillar (-38\%), followed by Knowledge and Technology Outputs (-28.7\%), and Human Capital and Research (-24.3\%). Regarding the Human Capital and Research, even though Portugal stands above Eurozone mean, there is still a considerable gap towards the top performers, meaning there is plenty of space for improvement in this area. 
Table 5. Portugal yearly scores versus Eurozone and Eurozone Top 3 means

\begin{tabular}{|c|c|c|c|c|c|c|c|}
\hline Variable & & 2013 & 2014 & 2015 & 2016 & 2017 & 2018 \\
\hline \multirow{5}{*}{ Input sub-index } & Portugal & 39.83 & 40.76 & 42.13 & 41.23 & 41.61 & 39.63 \\
\hline & Eurozone & 42.28 & 42.24 & 42.72 & 42.70 & 43.45 & 41.66 \\
\hline & Eurozone Top 3 & 48.46 & 48.68 & 49.01 & 48.55 & 49.07 & 47.10 \\
\hline & $\triangle$ PRT vs Eurozone & $-5.8 \%$ & $-3.5 \%$ & $-1.4 \%$ & $-3.4 \%$ & $-4.2 \%$ & $-4.9 \%$ \\
\hline & $\Delta$ PRT vs Top 3 & $-17.8 \%$ & $-16.3 \%$ & $-14.0 \%$ & $-15.1 \%$ & $-15.2 \%$ & $-15.9 \%$ \\
\hline \multirow{5}{*}{ Output sub-index } & Portugal & 35.35 & 34.30 & 36.27 & 34.00 & 33.75 & 33.88 \\
\hline & Eurozone & 37.83 & 36.24 & 36.87 & 36.05 & 35.02 & 35.04 \\
\hline & Eurozone Top 3 & 43.39 & 42.41 & 43.95 & 43.06 & 42.12 & 42.82 \\
\hline & $\triangle$ PRT vs Eurozone & $-6.6 \%$ & $-5.4 \%$ & $-1.6 \%$ & $-5.7 \%$ & $-3.6 \%$ & $-3.3 \%$ \\
\hline & $\Delta$ PRT vs Top 3 & $-18.5 \%$ & $-19.1 \%$ & $-17.5 \%$ & $-21.0 \%$ & $-19.9 \%$ & $-20.9 \%$ \\
\hline \multirow{5}{*}{ GII } & Portugal & 37.59 & 37.53 & 39.20 & 37.61 & 37.68 & 36.75 \\
\hline & Eurozone & 40.06 & 39.24 & 39.80 & 39.37 & 39.24 & 38.35 \\
\hline & Eurozone Top 3 & 45.25 & 45.24 & 46.14 & 45.77 & 45.41 & 44.52 \\
\hline & $\triangle \mathrm{PRT}$ vs Eurozone & $-6.2 \%$ & $-4.4 \%$ & $-1.5 \%$ & $-4.5 \%$ & $-4.0 \%$ & $-4.2 \%$ \\
\hline & $\Delta$ PRT vs Top 3 & $-16.9 \%$ & $-17.0 \%$ & $-15.0 \%$ & $-17.8 \%$ & $-17.0 \%$ & $-17.5 \%$ \\
\hline \multirow{5}{*}{$\begin{array}{l}\text { Innovation } \\
\text { Efficiency Index }\end{array}$} & Portugal & 0.887 & 0.842 & 0.861 & 0.825 & 0.811 & 0.855 \\
\hline & Eurozone & 0.897 & 0.859 & 0.862 & 0.844 & 0.805 & 0.840 \\
\hline & Eurozone Top 3 & 0.953 & 0.918 & 0.930 & 0.950 & 0.917 & 0.964 \\
\hline & $\triangle$ PRT vs Eurozone & $-1.1 \%$ & $-2.0 \%$ & $-0.1 \%$ & $-2.3 \%$ & $0.7 \%$ & $1.8 \%$ \\
\hline & $\Delta$ PRT vs Top 3 & $-6.9 \%$ & $-8.3 \%$ & $-7.4 \%$ & $-13.2 \%$ & $-11.6 \%$ & $-11.3 \%$ \\
\hline \multicolumn{8}{|c|}{ Input pillars: } \\
\hline \multirow{5}{*}{ Institutions } & Portugal & 54.54 & 57.32 & 60.66 & 60.44 & 61.42 & 60.24 \\
\hline & Eurozone & 59.82 & 59.44 & 60.14 & 60.71 & 60.72 & 59.74 \\
\hline & Eurozone Top 3 & 70.00 & 69.58 & 68.73 & 69.00 & 67.70 & 66.94 \\
\hline & $\triangle \mathrm{PRT}$ vs Eurozone & $-8.8 \%$ & $-3.6 \%$ & $0.9 \%$ & $-0.4 \%$ & $1.2 \%$ & $0.8 \%$ \\
\hline & $\Delta$ PRT vs Top 3 & $-22.1 \%$ & $-17.6 \%$ & $-11.7 \%$ & $-12.4 \%$ & $-9.3 \%$ & $-10.0 \%$ \\
\hline \multirow{5}{*}{$\begin{array}{c}\text { Human Capital and } \\
\text { Research }\end{array}$} & Portugal & 37.25 & 36.89 & 37.89 & 37.21 & 36.37 & 31.60 \\
\hline & Eurozone & 36.32 & 35.16 & 36.36 & 35.99 & 35.98 & 31.44 \\
\hline & Eurozone Top 3 & 48.73 & 48.06 & 48.29 & 48.95 & 57.17 & 41.74 \\
\hline & $\triangle \mathrm{PRT}$ vs Eurozone & $2.6 \%$ & $4.9 \%$ & $4.2 \%$ & $3.4 \%$ & $1.1 \%$ & $0.5 \%$ \\
\hline & $\Delta$ PRT vs Top 3 & $-23.6 \%$ & $-23.2 \%$ & $-21.5 \%$ & $-24.0 \%$ & $-36.4 \%$ & $-24.3 \%$ \\
\hline \multirow{5}{*}{ Infrastructure } & Portugal & 40.63 & 42.65 & 45.35 & 47.94 & 50.00 & 49.48 \\
\hline & Eurozone & 43.71 & 44.95 & 48.15 & 50.42 & 53.19 & 52.64 \\
\hline & Eurozone Top 3 & 50.90 & 52.64 & 54.54 & 56.59 & 57.63 & 58.82 \\
\hline & $\triangle \mathrm{PRT}$ vs Eurozone & $-7.0 \%$ & $-5.1 \%$ & $-5.8 \%$ & $-4.9 \%$ & $-6.0 \%$ & $-6.0 \%$ \\
\hline & $\Delta$ PRT vs Top 3 & $-20.2 \%$ & $-19.0 \%$ & $-16.9 \%$ & $-16.1 \%$ & $-13.2 \%$ & $-15.9 \%$ \\
\hline \multirow{5}{*}{ Market Sophistication } & Portugal & 43.16 & 43.28 & 42.25 & 37.66 & 37.01 & 36.25 \\
\hline & Eurozone & 41.74 & 42.24 & 40.20 & 37.79 & 37.76 & 37.51 \\
\hline & Eurozone Top 3 & 51.20 & 51.02 & 48.67 & 45.88 & 44.70 & 43.97 \\
\hline & $\triangle$ PRT vs Eurozone & $3.4 \%$ & $2.5 \%$ & $5.1 \%$ & $-0.3 \%$ & $-2.0 \%$ & $-3.4 \%$ \\
\hline & $\Delta$ PRT vs Top 3 & $-15.7 \%$ & $-15.2 \%$ & $-13.2 \%$ & $-17.9 \%$ & $-17.2 \%$ & $-17.6 \%$ \\
\hline \multirow{5}{*}{$\begin{array}{c}\text { Business } \\
\text { Sophistication }\end{array}$} & Portugal & 23.55 & 23.64 & 24.47 & 22.87 & 23.24 & 20.56 \\
\hline & Eurozone & 29.81 & 29.43 & 28.77 & 28.58 & 29.58 & 26.97 \\
\hline & Eurozone Top 3 & 37.97 & 36.16 & 36.34 & 35.36 & 36.50 & 33.15 \\
\hline & $\triangle$ PRT vs Eurozone & $-21.0 \%$ & $-19.7 \%$ & $-14.9 \%$ & $-20.0 \%$ & $-21.4 \%$ & $-23.8 \%$ \\
\hline & $\Delta$ PRT vs Top 3 & $-38.0 \%$ & $-34.6 \%$ & $-32.7 \%$ & $-35.3 \%$ & $-36.3 \%$ & $-38.0 \%$ \\
\hline \multicolumn{8}{|c|}{ Output pillars: } \\
\hline \multirow{5}{*}{$\begin{array}{l}\text { Knowledge and } \\
\text { Technology Outputs }\end{array}$} & Portugal & 21.53 & 20.84 & 22.53 & 22.31 & 23.01 & 20.93 \\
\hline & Eurozone & 25.45 & 24.03 & 23.84 & 24.60 & 24.85 & 22.79 \\
\hline & Eurozone Top 3 & 31.74 & 30.74 & 30.95 & 32.17 & 32.03 & 29.35 \\
\hline & $\triangle$ PRT vs Eurozone & $-15.4 \%$ & $-13.3 \%$ & $-5.5 \%$ & $-9.3 \%$ & $-7.4 \%$ & $-8.2 \%$ \\
\hline & $\Delta$ PRT vs Top 3 & $-32.2 \%$ & $-32.2 \%$ & $-27.2 \%$ & $-30.6 \%$ & $-28.2 \%$ & $-28.7 \%$ \\
\hline \multirow{5}{*}{ Creative Outputs } & Portugal & 49.17 & 47.76 & 50.01 & 45.68 & 44.49 & 46.83 \\
\hline & Eurozone & 50.22 & 48.45 & 49.90 & 47.50 & 45.19 & 47.28 \\
\hline & Eurozone Top 3 & 54.26 & 55.56 & 57.38 & 56.54 & 51.93 & 57.33 \\
\hline & $\triangle$ PRT vs Eurozone & $-2.1 \%$ & $-1.4 \%$ & $0.2 \%$ & $-3.8 \%$ & $-1.5 \%$ & $-1.0 \%$ \\
\hline & $\Delta$ PRT vs Top 3 & $-9.4 \%$ & $-14.0 \%$ & $-12.8 \%$ & $-19.2 \%$ & $-14.3 \%$ & $-18.3 \%$ \\
\hline
\end{tabular}

Source: Own calculations.

\section{CONCEPTUAL MODEL, LITERATURE REVIEW AND HYPOTHESIS}

Having perceived Portugal's innovation position inside the Eurozone and possible areas for improvement, in this section we review the literature of national systems of innovation (NSI) and propose a conceptual model which intends to explain the 
relationship between innovation inputs and outputs. Therefore, we intend to relate this section's results to the previous contextual analyses, hence deriving policy implication for Portugal.

The national systems of innovations (NSI) perspective was introduced in the late 1980s (see Freeman, 1995; Lundvall, 1992; Nelson, 1993) and its diffusion among academic and policy circles has been surprisingly rapid (Teixeira, 2014). This approach, instead of focusing on specific aspects of innovation, takes on a more holistic perspective, emphasising the interactions between different actors and the influence of broader environmental factors, such as institutions (Edquist, 2006; Fagerberg et al., 2010). A consensual definitions of NSI is still non-existent. Freeman (1987: 1) considers it to be a "network of institutions in the public and private sector which activities and interactions initiate, modify, and diffuse new technologies". Similarly, Nelson (1993: 4) defines them as "a set of institutions whose interactions determine the innovative performance (...) of national firms". From a different perspective, Lundvall (1992: 13) sees them as "all parts and aspects of the economic structure and the institutional setup affecting learning as well as searching and exploring". Although these definitions differ from one another, they encompass communalities, such as the focus on the relationships between institutions and organisations, and the interactions between them.

The measurement of NSI is a topic of ongoing debate (Gault, 2018; Grupp and Schubert, 2010; Nelson et al., 2014; Smith, 2006). In a seminal contribution to this issue, Smith (2006) revisited the traditional indicators used to measure innovation (R\&D intensity and patents) as well as more recent approaches. In its conclusions, the author admitted that future developments could come from multi-indicator approaches. Indeed, several international organisations have developed efforts to measure NSI, such as the European Commission (Summary Innovation Index - SII), World Economic Forum (Global Competitiveness Report - GCR), Cornell University, INSEAD, and WIPO (Global Innovation Index - GII), the Organization for Economic Co-Operation and Development (OECD Science, Technology, and Industry Scoreboard - STI).

The main body of NSI research using composite indicators encompass four different types of research with distinctive methodologies associated. First, in-depth case studies use existing frameworks, such as the Global Competitiveness Report (GCR), the Summary Innovation Index (SII) or the GII to evaluate a country or region (Alfantookh and Bakry, 2015; Marxt and Brunner, 2013), usually by comparison with other countries or regions. Second, drawing from existing frameworks, several studies develop alternative indices to rank the relative position of countries or regions (Barragán-Ocaña et al., 2020; Edquist et al., 2018; ZabalaIturriagagoitia et al., 2007). This studies typically consider an input-output framework since they adopt an efficiency perspective of NSI by means of data envelopment analysis methodologies. Third, to identify optimal configurational conditions of innovation, authors made use the innovation dimensions of the GII framework and apply a fuzzy-set qualitative comparative analysis (Crespo and Crespo, 2016; Khedhaouria and Thurik, 2017). Lastly, studies aimed at identifying structural relationships between the various dimensions of innovation use the structural equations modelling methodology with both existing frameworks such as the GII (Sohn et al., 2016) and a collection of innovation indicators (Nasierowski and Arcelus, 1999). All of this research supports the notion that innovation inputs are transformed into innovative outputs. Also, Cornell University et al. (2018) describe a positive relationship between innovation inputs and outputs in every income groups, hence we propose the following hypothesis.

\section{H1: Innovation Inputs have a Positive Relationship with Innovation Outputs}

This pillar refers to the political environment (i.e. stability and effectiveness), the regulatory environment (i.e. rule of law and labour regulations), and business environment (i.e. ease of starting and ending a business). Institutions are understood as "humanly devised constraints that structure human interaction" (North, 1994: 360), which take the form of rules, laws, conventions or norms of behaviour. Lundvall (1992) recognised the institutional set up to be part of the national system of innovation, which, along with other factors, is capable of affect learning, searching, and exploring. Empirically, using patent grant data, Tebaldi and Elmslie (2013) found that institutional quality is positively related to patent counts across countries. On another study with a large sample of advanced and emerging economies, Silve and Plekhanov (2015) found that institutions are important determinants of innovation and, further still, that industries involving higher levels of innovation develop faster in countries with better economic institutions. Using GII data, Sohn et al. (2016) found a positive and indirect relationship between institutions and both knowledge and technological outputs and Creative Outputs. Previous research suggests that an institutional environment that provides good governance as well as protection and incentives is essential to innovation, hence we propose the following hypothesis.

\section{H2a: Institutions have a positive relationship with Knowledge and Technology Outputs.}

H2b: Institutions have a positive relationship with Creative Outputs.

Human capital and research pillar refer to countries' education (i.e. government expenditure and student performance), tertiary education (i.e. enrolment, mobility, and graduates) and research (i.e. researchers and R\&D intensity and activities). From the national systems of innovation perspective, education is one of the drivers of innovation (Freeman, 1995), encompassing university systems, available human capital resources, and the available knowledge stock (Abel and Deitz, 2012; Bendapudi et al., 2018; Freeman, 1995). Van Hiel et al. (2018), using a large sample of countries with great variation in terms of Human Development Index (HDI), found that increasing levels of education, in high HDI countries, translates into better scores on national indices of innovation through the increase of liberalisation values in such societies. Also, Suseno et al. (2018) found that human capital, as well as social capital, have a significant effect on national innovation performance. Regarding the role of research on innovation, Bilbao-Osorio and Rodriguez-Pose (2004) conclude that private R\&D activities are positively related to innovation in the European Union (EU). Sohn et al. (2016) found positive direct and indirect relationships between Human Capital and Research and both output pillars. Following the rationale where education can be considered an input to R\&D activities, consequently resulting in increased innovation at the country level, we propose the following hypothesis.

H3a: Human Capital and Research have a positive relationship with Knowledge and Technology Outputs.

H3b: Human Capital and Research have a positive relationship with Creative Outputs. 
Infrastructure pillar encompasses information and communication technologies (i.e. assess, use, and electronic government), general infrastructure (i.e. electricity, logistics, and physical infrastructures), and ecological sustainability (i.e. sound environmental practices). The infrastructural dimension assumes that good and ecological infrastructures facilitate the production and exchange of ideas, services and goods, which allows firms to increase their productivity, get better access to markets, and lower transaction costs (Arendt and Grabowski, 2017; Cornell University et al., 2018). For example, Cuevas-Vargas et al. (2016) found that the use of ICTs is a critical facilitator of innovation for micro, small, and medium sized enterprises in Mexico. Also, Martins and Veiga (2018) conclude that innovations in Portugal's electronic government can lead to a more business-friendly environment, by reducing the administrative and regulatory burden. When analysing the drivers of EU's circular economy, Cainelli et al. (2020) suggest that an environmental policy and green demand leads to an increase in eco-innovations by EU firms. Also, Sohn et al. (2016) discovered that Infrastructure has an indirect, positive, relationship with the two output pillars. Therefore, it is likely that well developed infrastructures positively affect innovation, hence we propose the following hypothesis.

\section{H4a: Infrastructure has a positive relationship with Knowledge and Technology Outputs.}

\section{H4b: Infrastructure has a positive relationship with Creative Outputs.}

Market sophistication pillar refers to domestic market quality, namely in terms of credit (i.e. ease of getting credit and its availability), investment (i.e. protection of minority investors and market value), and trade, competition, and market scale (i.e. tariff rates, competition, and GDP). Economic and finance literatures reveal a relationship between financial markets' development and economic growth (Beck and Levine, 2002; King and Levine, 1993; La Porta et al., 1998). Fagerberg and Srholec (2008) stressed the importance of a country's financial system in mobilising the necessary resources for innovation. Empirically, based on a three-decade panel of U.S. issued patents, Kortum and Lerner (2000) found that venture capital has a positive and significant impact on technological innovation. More recently, in a cross-country longitudinal study of the impact of financial market development on innovation, Hsu et al. (2014) found that industries more dependent on external financing and are hightech intensive exhibit higher innovation levels in countries with better developed equity markets. When analysing debtor's protection rights, Cerqueiro et al. (2017) suggest that when debtor's protection increases innovation decreases, due to a reduction in credit supply to small firms, particularly for those highly dependent on external financing. These findings are in line with those of Amore et al. (2013), who discovered that the availability and quality of credit by US banks had a positive impact on firms' innovation. Also, Sohn et al. (2016) discovered a positive direct relationship between this pillar and both output pillars. As such, following the rationale that a country with sophisticated financial markets has better conditions for innovation to thrive, we propose the following hypothesis.

\section{H5a: Market Sophistication has a positive relationship with Knowledge and Technology Outputs.}

\section{H5b: Market Sophistication has a positive relationship with Creative Outputs.}

Business Sophistication pillar refers to knowledge workers (i.e. human capital employed by businesses), innovation linkages (i.e. linkages and partnerships between private, public and academic actors), and knowledge absorption (i.e. all high-tech and ICTs imports, intellectual property payments, FDI inflows, and researchers in business enterprises). For instance, Love and Mansury (2007), studying US business services, found that a highly qualified working force increases the probability of innovation. The authors also found that external linkages improve innovation performance. A study on Italian firms conducted by Maietta (2015) suggests that R\&D collaboration between firms and universities have an impact on process innovation and a positive effect on product innovation for firms geographically closer to such entities. Also, Díez-Vial and Montoro-Sánchez (2016) found a positive relationship between the knowledge obtained by technology firms from universities and their levels of innovation. Regarding knowledge absorption, Liu and Zou (2008) found that R\&D greenfield FDI significantly affects the innovation performance of domestic firms, finding evidence of both intra- and inter-industry spillovers. Also, Bertschek (1995) and Blind and Jungmittag (2004) found that both imports and inward FDI have positive and significant effects on product and process innovations. These results are in line with Khan and $\mathrm{Yu}$ (2019) suggestion that innovation is one the reasons why firms opt for global sourcing. Also, Sohn et al. (2016) discovered a positive direct relationship between the Business Sophistication pillar and the Creative Outputs pillar. Therefore, a country with higher business sophistication is likely to produce more innovative outputs, thus we propose the following hypothesis.

H6a: Business Sophistication has a positive relationship with Knowledge and Technology Outputs. H6b: Business Sophistication has a positive relationship with Creative Outputs.

Figure 2 shows the proposed conceptual model, in which arrows represent the hypothesis developed above. 


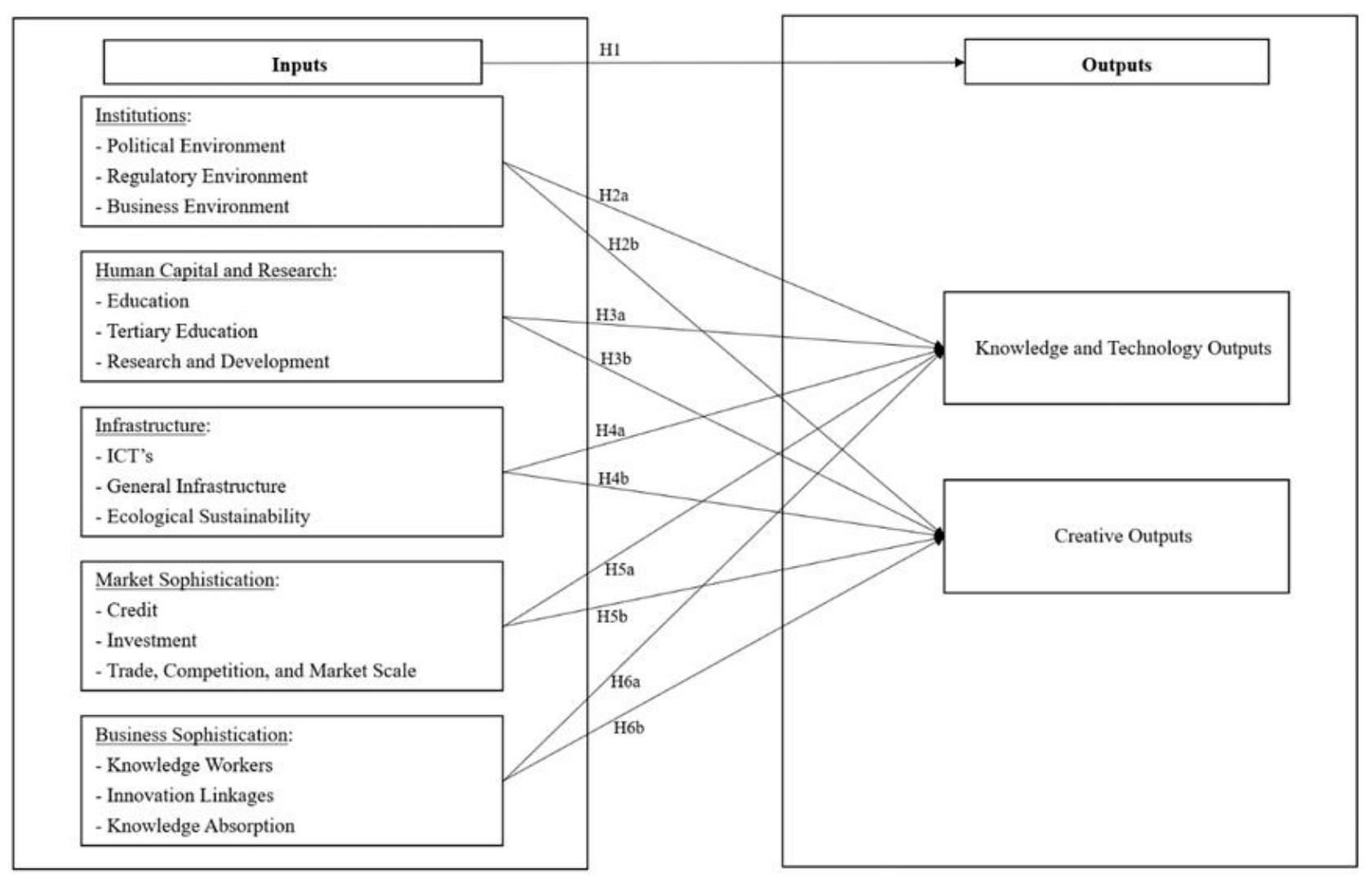

Figure 2. Conceptual model Source: Own elaboration.

\section{METHODOLOGY}

Based on the DuCa framework put forth in section 3, we have developed a number of regression models in order to test the proposed hypothesis. We then applied the same models to a sub-sample composed exclusively of Eurozone members, in order to understand the behaviour of such relationships inside the European Monetary Union (EMU). All regressions were estimated using Gretl software (Cottrell and Lucchetti, 2009).

\section{Data and Sample}

As mentioned above, we have developed a panel dataset composed by 92 countries (see Table A2 in Appendix) during the period 2013 to 2018. Besides GII raw data, other sources were used, namely the International Labour Organization statistics (ILOSTAT), the UNESCO Institute for Statistics (UIS), the UN Comtrade database, the World Development Indicators from the World Bank, the World Intellectual Property Organization (WIPO) database, and the World Trade Organization (WTO) DATA.

\section{Variables}

Dependent variables. To analyse the relationship between innovation inputs and outputs, we used three dependent variables in separate models. First, the output sub-index (lout) is used to assess the effect of inputs on the overall score of innovation outputs. Then, we used the two output pillars (Knowledge and Technology Outputs (O6) and Creative Outputs (O7)) to further investigate the effects of innovation inputs in each outcome.

Independent variables. The explanatory variables used are the scores of the innovation input sub-index (lin) and the five input pillars, Institutions (11), Human Capital and Research (12), Infrastructure (13), Market Sophistication (14), and Business Sophistication (15).

\section{Model Specification}

When conducting linear regressions with panel data, several estimators could be used, being the most common the pooled ordinary least squares (pOLS), the fixed effects estimator (FE), and the random effects estimator (RE) (Baltagi, 2015; Wooldridge, 2016). To choose an appropriate estimator, one must consider the nature and source of the data, as well as the methodology used to obtain it (for a discussion, see Hsiao, 2007). Apart from the theoretical discussion, Gretl provides a set of three statistical tests can be used to choose a particular estimator, namely an F test, in which the null hypothesis favours pOLS and the alternative the FE estimator, a Breusch-Pagan test, in which the null hypothesis favours pOLS and the alternative the RE estimator, and the Hausman test, in which the null hypothesis favours the RE estimator and the alternative the FE estimator. 
Table 6. Descriptive statistics, correlation matrix and variance inflation factors (VIF)

\begin{tabular}{|c|c|c|c|c|c|c|c|c|c|c|c|c|}
\hline & $\mathbf{N}$ & Mean & S.D. & lout & 06 & 07 & lin & I1 & 12 & 13 & 14 & 15 \\
\hline lout & 552 & 28.16 & 8.26 & - & & & & & & & & \\
\hline 06 & 552 & 19.42 & 6.10 & 0.908 & - & & & & & & & \\
\hline 07 & 552 & 36.89 & 11.27 & 0.974 & 0.789 & - & & & & & & \\
\hline lin & 552 & 35.08 & 9.05 & 0.894 & 0.835 & 0.858 & - & & & & & \\
\hline I1 & 552 & 50.63 & 12.02 & 0.784 & 0.668 & 0.787 & 0.907 & 3.387 & & & & \\
\hline 12 & 552 & 25.41 & 12.58 & 0.867 & 0.840 & 0.816 & 0.925 & 0.769 & 4.189 & & & \\
\hline 13 & 552 & 41.68 & 10.25 & 0.735 & 0.708 & 0.694 & 0.885 & 0.768 & 0.784 & 3.197 & & \\
\hline 14 & 552 & 35.98 & 8.62 & 0.694 & 0.631 & 0.675 & 0.812 & 0.700 & 0.683 & 0.612 & 2.212 & \\
\hline 15 & 552 & 21.69 & 7.75 & 0.853 & 0.837 & 0.797 & 0.857 & 0.701 & 0.792 & 0.705 & 0.630 & 2.945 \\
\hline
\end{tabular}

Source: Own calculations.

Note: Correlations values above 0.0835 are significant at the $5 \%$ level (two-tailed). VIF values are presented in the diagonal, in bold. lout: Output sub-index; 06: Knowledge and technology outputs; 07: Creative outputs; lin: Input sub-index; I1: Institutions; I2: Human capital and research; I3: Infrastructure; 14: Market sophistication; 15: Business sophistication.

In this sense, we developed four models in both pOLS and FE specification. The RE specification was not used, since the three tests indicated that a FE approach was appropriate. Therefore, to test hypothesis $\mathrm{H} 1$, we developed the following models:

$$
\begin{gathered}
\text { Iout }_{i t}=\beta_{0}+\beta_{1} \text { Iin }_{i t}+\delta_{1} d 14_{t}+\delta_{2} d 15_{t}+\delta_{3} d 16_{t}+\delta_{4} d 17_{t}+\delta_{5} d 18_{t}+\alpha_{i}+\mu_{i t} \\
\text { Iout }_{i t}=\beta_{1} \text { Iin }_{i t}+\delta_{1} d 14_{t}+\delta_{2} d 15_{t}+\delta_{3} d 16_{t}+\delta_{4} d 17_{t}+\delta_{5} d 18_{t}+\alpha_{i}+\mu_{i t}
\end{gathered}
$$

Where, lout is the dependent variable for each country $(i)$ in each year $(t), \beta_{0}$ is the intercept, $\beta_{1}$ is the slope of the variable of interest, $\delta_{k}(K=1,2,3,4,5)$ are the coefficients of year dummies included in the regression, $\alpha_{i}$ is the individual fixed effect that does not vary over time, and $\mu_{i t}$ is the idiosyncratic error. We follow Wooldridge (2016) recommendation to include time dummies if $\mathrm{T}$ is small relative to $\mathrm{N}$ (in this case, $\mathrm{T}=6$ and $\mathrm{N}=92$ ), to capture secular changes that are not being modelled. Eq. 1 refers to the pOLS specification. Eq. 2 to the FE specification, which does not include a constant.

The following models were developed to test hypothesis $\mathrm{H} 2 \mathrm{a}, \mathrm{H} 3 \mathrm{a}, \mathrm{H} 4 \mathrm{a}, \mathrm{H} 5 \mathrm{a}$, and $\mathrm{H} 6 \mathrm{a}$ :

$$
\begin{gathered}
O 6_{i t}=\beta_{0}+\beta_{1} I 1_{i t}+\beta_{2} I 2_{i t}+\beta_{3} I 3_{i t}+\beta_{4} I 4_{i t}+\beta_{5} I 5_{i t}+\delta_{1} d 14_{t}+\delta_{2} d 15_{t}+\delta_{3} d 16_{t}+\delta_{4} d 17_{t}+\delta_{5} d 18_{t}+\alpha_{i}+\mu_{i t} \\
O 6_{i t}=\beta_{1} I 1_{i t}+\beta_{2} I 2_{i t}+\beta_{3} I 3_{i t}+\beta_{4} I 4_{i t}+\beta_{5} I 5_{i t}+\delta_{1} d 14_{t}+\delta_{2} d 15_{t}+\delta_{3} d 16_{t}+\delta_{4} d 17_{t}+\delta_{5} d 18_{t}+\alpha_{i}+\mu_{i t}
\end{gathered}
$$

Where Eq. 3 refers to the pOLS specification and Eq. 4 to FE.

Lastly, to test hypothesis $\mathrm{H} 2 \mathrm{~b}, \mathrm{H} 3 \mathrm{~b}, \mathrm{H} 4 \mathrm{~b}, \mathrm{H} 5 \mathrm{~b}$, and $\mathrm{H} 6 \mathrm{~b}$, we developed the following models:

$$
\begin{gathered}
O 7_{i t}=\beta_{0}+\beta_{1} I 1_{i t}+\beta_{2} I 2_{i t}+\beta_{3} I 3_{i t}+\beta_{4} I 4_{i t}+\beta_{5} I 5_{i t}+\delta_{1} d 14_{t}+\delta_{2} d 15_{t}+\delta_{3} d 16_{t}+\delta_{4} d 17_{t}+\delta_{5} d 18_{t}+\alpha_{i}+\mu_{i t} \\
O 7_{i t}=\beta_{1} I 1_{i t}+\beta_{2} I 2_{i t}+\beta_{3} I 3_{i t}+\beta_{4} I 4_{i t}+\beta_{5} I 5_{i t}+\delta_{1} d 14_{t}+\delta_{2} d 15_{t}+\delta_{3} d 16_{t}+\delta_{4} d 17_{t}+\delta_{5} d 18_{t}+\alpha_{i}+\mu_{i t}
\end{gathered}
$$

Where Eq. 5 refers to pOLS specification and Eq. 6 to FE.

\section{RESULTS AND DISCUSSION}

Table 6 shows the main descriptive statistics, the correlation matrix, and variance inflation factors (VIF). An analysis of the correlation matrix reveals the existence of significant correlations between the variables. Although a high correlation was expected between the input and output sub-indexes and their respective pillars, the existing correlations between the five input pillars could result in multicollinearity issues when regressed together. However, the highest VIF value (4.189 for variable I3) is below the common rule of thumb of 10 (Wooldridge, 2016), which indicates that multicollinearity should not be a problem.

Tables 7 and $\mathbf{8}$ displays the results of the regressions used to test our hypothesis. Starting with the simple pooled OLS (pOLS), we can see that all panel tests indicate that a fixed effect (FE) approach is adequate. Together, the F, Breusch-Pagan, and Hausman tests reject the pOLS and random effects (RE) specifications, in favour of the FE approach. Also, the Welch F test rejects the null hypothesis that groups have a common intercept, thus rendering pOLS inadequate. Regarding the inclusion of time dummies, a Wald joint test rejects the null hypothesis of no time effects. Both pOLS and FE specifications are reported, however only the results from FE are discussed.

With the first model we intended to test if, in our sample, innovation inputs (lin) are, in fact, transformed into innovation outputs (lout) (Column 2, Table 7). Results reveal a surprising negative relationship between Innovation Inputs and Outputs subindices, although without statistical significance. This seems to contradict Cornell University et al. (2018), however, the authors obtained such evidence using an OLS estimator in a cross-sectional sample and our pOLS results (Column 1, Table 7) seem to corroborate this finding. Therefore, our results do not support Hypothesis $\mathrm{H} 1$. 
Table 7. Results of regressions

\begin{tabular}{|c|c|c|}
\hline Dependent Variable & & \\
\hline \multirow{2}{*}{ Model } & pOLS & $\mathrm{FE}$ \\
\hline & $(1)$ & (2) \\
\hline \multirow{2}{*}{ Const. } & $1.814 \dagger$ & - \\
\hline & $(1.060)$ & \\
\hline \multirow{2}{*}{ lin } & $0.832^{\star \star \star}$ & -0.089 \\
\hline & $(0.031)$ & $(0.079)$ \\
\hline $\mathbf{N}$ & 552 & 552 \\
\hline Adj. $R^{2}$ & 0.8483 & \\
\hline Within $\mathbf{R}^{2}$ & & 0.5327 \\
\hline BIC & 2893.288 & 2395.491 \\
\hline Time dummies & Yes & Yes \\
\hline Wald F $(5,91)$ & $77.141^{\star \star \star}$ & $53.201^{\star \star \star}$ \\
\hline \multicolumn{3}{|l|}{ Panel tests: } \\
\hline$F(91,454)$ & $29.820^{\star \star \star}$ & \\
\hline Breusch-Pagan & $754.472^{\star \star \star}$ & \\
\hline Hausman & $185.983^{\star \star \star}$ & \\
\hline Welch F $(91,156.7)$ & & $24.503^{\star \star \star}$ \\
\hline
\end{tabular}

Source: Own calculation.

Note: $\dagger p \leq 0.1 ;{ }^{\star} p \leq 0.05 ;{ }^{\star \star} p \leq 0.01 ;{ }^{\star \star \star} p \leq 0.001$. Below the coefficients are heteroskedasticity and autocorrelation (HAC) robust standard errors, in parenthesis. lout: Output sub-index; lin: Input sub-index; I1: Institutions; I2: Human capital and research; I3: Infrastructure; I4: Market sophistication; 15: Business sophistication; pOLS: Pooled OLS estimator; FE: Fixed effects estimator.

Table 8. Results of regressions (continuation)

\begin{tabular}{|c|c|c|c|c|}
\hline \multirow{3}{*}{$\begin{array}{c}\text { Dependent Variable } \\
\text { Model }\end{array}$} & \multicolumn{2}{|c|}{06} & \multicolumn{2}{|c|}{07} \\
\hline & pOLS & $\mathrm{FE}$ & pOLS & $\mathrm{FE}$ \\
\hline & (3) & (4) & (5) & (6) \\
\hline \multirow{2}{*}{ Const. } & $5.473^{\star \star \star}$ & - & $4.813 \dagger$ & - \\
\hline & $(1.304)$ & & $(2.653)$ & \\
\hline \multirow{2}{*}{ I1 } & -0.054 & -0.049 & $0.267^{\star \star \star}$ & -0.122 \\
\hline & $(0.047)$ & $(0.033)$ & $(0.051)$ & $(0.083)$ \\
\hline \multirow{2}{*}{12} & $0.213^{\star \star \star}$ & 0.018 & $0.184^{\star}$ & $-0.088^{\star}$ \\
\hline & $(0.038)$ & $(0.029)$ & $(0.075)$ & $(0.044)$ \\
\hline \multirow{2}{*}{13} & $0.075 \dagger$ & 0.047 & $0.220^{\star \star}$ & -0.081 \\
\hline & $(0.045)$ & $(0.036)$ & $(0.082)$ & $(0.064)$ \\
\hline \multirow{2}{*}{14} & 0.032 & -0.020 & 0.011 & -0.107 \\
\hline & $(0.042)$ & $(0.040)$ & $(0.072)$ & $(0.080)$ \\
\hline \multirow{2}{*}{15} & $0.348^{\star \star \star}$ & $0.079 \dagger$ & $0.424^{\star \star \star}$ & 0.099 \\
\hline & $(0.057)$ & $(0.041)$ & $(0.089)$ & $(0.067)$ \\
\hline $\mathbf{N}$ & 552 & 552 & 552 & 552 \\
\hline Adj. $\mathrm{R}^{2}$ & 0.7885 & & 0.8285 & \\
\hline Within $\mathbf{R}^{2}$ & & 0.2847 & & 0.5693 \\
\hline BIC & 2763.213 & 2140.114 & 3325.905 & 3036.776 \\
\hline Time dummies & Yes & Yes & Yes & Yes \\
\hline Wald F $(5,91)$ & $5.370^{\star \star \star}$ & $21.492^{\star \star \star}$ & $48.484^{\star \star \star}$ & $37.984^{\star \star \star}$ \\
\hline \multicolumn{5}{|l|}{ Panel tests: } \\
\hline$F(91,450)$ & $38.325^{\star \star \star}$ & & $18.696^{\star \star \star}$ & \\
\hline Breusch-Pagan & $836.190^{\star \star \star}$ & & $570.579^{\star \star \star}$ & \\
\hline Hausman & $116.239^{\star \star \star}$ & & $159.923^{\star \star \star}$ & \\
\hline Welch F $(91,156.7)$ & & $47.884^{\star \star \star}$ & & $18.582^{\star \star \star}$ \\
\hline
\end{tabular}

Source: Own calculation.

Note: $\uparrow p \leq 0.1 ;{ }^{\star} p \leq 0.05 ;{ }^{\star \star} p \leq 0.01 ;{ }^{\star \star \star} p \leq 0.001$. Below the coefficients are heteroskedasticity and autocorrelation (HAC) robust standard errors, in parenthesis. 06: Knowledge and technology outputs; 07: Creative outputs; I1: Institutions; I2: Human capital and research; I3: Infrastructure; I4: Market sophistication; I5: Business sophistication; pOLS: Pooled OLS estimator; FE: Fixed effects estimator.

Table 8 shows the results of regressing the five input pillars on both output pillars. When analysing the effects of input pillars on Knowledge and Technology Outputs (06) (Column 4, Table 8), we found that only Business Sophistication has a significant effect ( $\mathrm{p}=0.0575$ ) with a positive sign, thus supporting Hypothesis $\mathrm{H} 6 \mathrm{a}$. As such, results do not support Hypothesis $\mathrm{H} 2 \mathrm{a}, \mathrm{H} 3 \mathrm{a}, \mathrm{H} 4 \mathrm{a}$, and H5a. However, we also found negative effects, albeit not statistically significant, of Institutions (I1) and Market Sophistication (14) on Knowledge and Technology Outputs (O6). On Column 6 (Table 8), only Human Capital and Research (I2) was found to have a statistically significant relationship with Creative Outputs $(\mathrm{O})(\mathrm{p}=0.0483)$ which, having a negative sign, rejects Hypothesis $\mathrm{H} 3 \mathrm{~b}$. The remaining input pillars did not attain statistical significance, hence failing to support Hypothesis $\mathrm{H} 2 \mathrm{~b}, \mathrm{H} 4 \mathrm{~b}, \mathrm{H} 5 \mathrm{~b}$, and H6b.

Of the two output pillars, results suggest that Business Sophistication relates more to the traditional measures of innovation (i.e., Knowledge and Technology Outputs) than to more creative forms of innovation (i.e., Creative Outputs), suggesting that the employment of knowledge workers, the quality of linkages between public organisations, universities, and private firms, and the 
Table 9. Results of Fixed Effects regressions (Eurozone sub-sample)

\begin{tabular}{|c|c|c|c|}
\hline Dependent Variable & lout & 06 & 07 \\
\hline \multirow{2}{*}{ Model } & $\mathrm{FE}$ & $\mathrm{FE}$ & $\mathrm{FE}$ \\
\hline & $(7)$ & (8) & (9) \\
\hline \multirow{2}{*}{ lin } & 0.254 & - & - \\
\hline & $(0.226)$ & & \\
\hline \multirow{2}{*}{$\mathbf{I 1}$} & - & 0.055 & -0.093 \\
\hline & & $(0.142)$ & $(0.115)$ \\
\hline \multirow{2}{*}{12} & - & 0.007 & -0.117 \\
\hline & & $(0.048)$ & $(0.073)$ \\
\hline \multirow{2}{*}{13} & - & 0.091 & -0.095 \\
\hline & & $(0.114)$ & $(0.089)$ \\
\hline \multirow{2}{*}{14} & - & -0.025 & 0.023 \\
\hline & & $(0.118)$ & $(0.126)$ \\
\hline \multirow{2}{*}{15} & - & $0.298 \dagger$ & $0.300^{\star}$ \\
\hline & & $(0.153)$ & $(0.132)$ \\
\hline $\mathbf{N}$ & 111 & 111 & 111 \\
\hline Within $\mathbf{R}^{2}$ & 0.3893 & 0.4183 & 0.6183 \\
\hline BIC & 447.751 & 466.980 & 516.625 \\
\hline Time dummies & Yes & Yes & Yes \\
\hline Wald F $(5,18)$ & $14.896^{\star \star \star}$ & $8.153^{\star \star \star}$ & $18.993^{\star \star \star}$ \\
\hline
\end{tabular}

Source: Own calculation.

Note: $\uparrow p \leq 0.1 ;{ }^{\star} p \leq 0.05 ;{ }^{\star \star} p \leq 0.01 ;{ }^{\star \star \star} p \leq 0.001$. Below the coefficients are heteroskedasticity and autocorrelation (HAC) robust standard errors, in parenthesis. lout: Output sub-index; 06: Knowledge and technology outputs; 07: Creative outputs; lin: Input sub-index; I1: Institutions; I2: Human capital and research; I3: Infrastructure; 14: Market sophistication; 15: Business sophistication; FE: Fixed effects estimator.

economy's knowledge absorption capacity are strong inducers of technological innovation. Similar conclusions can be found in several studies (Bertschek, 1995; Blind and Jungmittag, 2004; Díez-Vial and Montoro-Sánchez, 2016; Liu and Zou, 2008; Love and Mansury, 2007; Maietta, 2015).The negative relationship observed between Human Capital and Research and Creative Outputs could probably be one of methodological concern. One could argue that investments in education and research are not instantaneously transformed into innovation outputs. To this end, we have introduced time lags, up to two years, in this variable. In both cases, it loses its statistical significance but remains with a negative sign. It is likely that longer time-series are needed to properly assess this relationship. It is also likely that mediating and/or moderating effects could be present, as noted by Sohn et al. (2016), thus explaining the negative direct relationship. Also, by pooling a large number of countries with very different levels of development of education, research and innovation, the negative influences could outweigh the positive ones in our sample.

\section{Eurozone Analyses}

In order to approximate our estimations to Portugal, in this section we conduct similar analyses with a Eurozone sub-sample. Therefore, results could serve as references to derive policy implication for Portugal. Table 9 presents the results of FE regressions conducted in the Eurozone sub-sample, which is composed by the 19 countries using the Euro during the period 2013-2018, excluding Latvia in 2013 and Lithuania in 2013 and 2014 since their affiliation happened afterwards. Only FE regressions are presented for the sake of brevity, but pOLS estimations are available upon request.

Contrary to previous findings using the full sample (Column 2, Table 7), the relationship between innovation inputs and outputs changes its sign in Eurozone countries, although without attaining statistical significance $(p=0.2763)$. By analysing the five input pillars, only Business Sophistication revealed a positive statistically significant relationship with both Knowledge and Technology Outputs (06) (Column 8, Table 9) and Creative Outputs (07) (Column 9, Table 9), with $p=0.0678$ and $p=0.0361$, respectively. The relationship with Creative Outputs now visible, is in line with findings of Sohn, Kim and Jeon (2016). Although none of the remaining input pillars showed a statistically significant relationship with either Knowledge and Technology Outputs or Creative Outputs, their signs change according to the dependent variable used. While Institutions (I1), Human Capital and Research (12), and Infrastructure (13) showed a positive sign when regressed over Knowledge and Technology Outputs, those variables revealed a negative sign when regressed over Creative Outputs, with Market Sophistication (14) having the opposite behaviour.

Next, we make a deeper analysis of the Eurozone sub-sample, by decomposing the five input pillars into their 15 input subpillars (Table 10) and using them as explanatory variables.

This detailed analysis reveals which sub-pillars are responsible for the results presented above in the Eurozone sub-sample. A negative and statistically significant relationship was found between Research and Development (123) and Creative Outputs ( $p=$ 0.0013) (Column 15, Table 10), while the same statistical significance is not present regarding its relationship with Knowledge and Technology Outputs (O6), albeit remaining with a negative sign (Column 14, Table 10). This result could be due to different R\&D sectors. Bilbao-Osorio and Rodriguez-Pose (2004) argue that public R\&D may not be a net contributor to the innovation process since it is mainly associated with basic research. Ecological Sustainability (I33) shows a positive, statistically significant, relationship with Knowledge and Technology Outputs $(p=0.0048)$. This is in line with Cainelli et al. (2020), who suggest that environmental policies drive the adoption of eco-innovation by firms. Trade, Competition, and Market Scale (143) also presents a positive and statistically significant relationship, below the $10 \%$ level, with Creative Outputs $(p=0.0718)$. Perhaps the most revealing result is the positive relationship, with a strong statistical significance, between Knowledge Absorption (I53) and both 
Table 10. Results of Fixed Effects regressions using all input sub-pillars (Eurozone sub-sample)

\begin{tabular}{|c|c|c|}
\hline Dependent Variable & 06 & 07 \\
\hline \multirow{2}{*}{ Model } & $\mathrm{FE}$ & $\mathrm{FE}$ \\
\hline & $(10)$ & (11) \\
\hline \multirow{2}{*}{ I11 } & 0.035 & 0.113 \\
\hline & $(0.116)$ & $(0.183)$ \\
\hline \multirow{2}{*}{112} & 0.023 & -0.151 \\
\hline & $(0.039)$ & $(0.095)$ \\
\hline \multirow{2}{*}{ I13 } & 0.032 & 0.036 \\
\hline & $(0.067)$ & $(0.066)$ \\
\hline \multirow{2}{*}{121} & 0.025 & -0.005 \\
\hline & $(0.021)$ & $(0.032)$ \\
\hline \multirow{2}{*}{122} & -0.093 & -0.093 \\
\hline & $(0.090)$ & $(0.056)$ \\
\hline \multirow{2}{*}{123} & -0.042 & $-0.165^{\star \star}$ \\
\hline & $(0.033)$ & $(0.043)$ \\
\hline \multirow{2}{*}{131} & -0.014 & -0.065 \\
\hline & $(0.043)$ & $(0.043)$ \\
\hline \multirow{2}{*}{132} & -0.002 & -0.035 \\
\hline & $(0.097)$ & $(0.101)$ \\
\hline \multirow{2}{*}{133} & $0.163^{\star \star}$ & 0.065 \\
\hline & $(0.051)$ & $(0.088)$ \\
\hline \multirow{2}{*}{141} & -0.047 & -0.003 \\
\hline & $(0.053)$ & $(0.072)$ \\
\hline \multirow{2}{*}{142} & 0.018 & -0.018 \\
\hline & $(0.055)$ & $(0.057)$ \\
\hline \multirow{2}{*}{143} & 0.168 & $0.205 \dagger$ \\
\hline & $(0.108)$ & $(0.107)$ \\
\hline \multirow{2}{*}{151} & 0.037 & 0.078 \\
\hline & $(0.052)$ & $(0.077)$ \\
\hline \multirow{2}{*}{152} & -0.019 & -0.013 \\
\hline & $(0.059)$ & $(0.107)$ \\
\hline \multirow{2}{*}{153} & $0.228^{\star \star}$ & $0.195^{\star \star \star}$ \\
\hline & $(0.069)$ & $(0.041)$ \\
\hline $\mathbf{N}$ & 111 & 111 \\
\hline Within $\mathbf{R}^{2}$ & 0.5795 & 0.6785 \\
\hline BIC & 478.036 & 544.667 \\
\hline Time dummies & Yes & Yes \\
\hline Wald F $(5,18)$ & $6.186^{\star \star}$ & $9.807^{\star \star \star}$ \\
\hline
\end{tabular}

Source: Own calculation.

Note: $\dagger p \leq 0.1 ;{ }^{\star} p \leq 0.05 ;{ }^{\star \star} p \leq 0.01 ;{ }^{\star \star \star} p \leq 0.001$. Below the coefficients are heteroskedasticity and autocorrelation (HAC) robust standard errors, in parenthesis. 06: Knowledge and technology outputs; 07: Creative outputs; I11: Political environment; I12: Regulatory environment; I13; Business environment; 121: Education; I22: Tertiary education; I23: Research and development; I31: Information and communication technologies; 132: General infrastructure; I33: Ecological sustainability; 141: Credit; I42: Investment; 143: Trade, competition, and market scale; I51: Knowledge workers; 152: Innovation linkages; 153: Knowledge absorption; FE: Fixed effects estimator.

Knowledge and Technology Outputs $(p=0.0041)$ and Creative Outputs $(p=0.0002)$. This is in line with the absorption capacity perspective (Cohen and Levinthal, 1990), in which the ability to recognise and incorporate external knowledge into the firm's products and processes leads to higher levels of innovation (Gkypali et al., 2018).

\section{Implications for Portugal}

Following the results obtained in previous section, we now derive some policy implication for Portugal regarding improvements in its comparative levels of innovation. We start with a simple exercise, with which we intend to demonstrate the importance of certain policies on the convergence of Portugal with the Eurozone. First, we have selected the Knowledge Absorption sub-pillar due its significant effects on both innovations outputs and because it belongs to the pillar in which Portugal has a larger gap towards the Eurozone. Then, we have computed the difference between Portugal average score (25.356) and Eurozone's (32.410) (averages for the period 2013-2018). The value was then multiplied by the estimated coefficient of Knowledge Absorption (153) in each of the regressions presented in Table 10. The same reasoning was made for the top Eurozone performer, which, for this sub-pillar, is the Netherlands (48.441).

Table 11 shows potential benefits for innovation outputs if policies are developed to improve Business Sophistication areas in Portugal, namely those related to Knowledge Absorption. As mentioned above, Business Sophistication is the area where Portugal has a larger gap toward the Eurozone, having an average difference of $20 \%$ to other Eurozone countries and more than $35 \%$ to Eurozone top performers. Recalling Table 10, policies towards the attraction of FDI, or incentives to high-tech imports, are likely to enhance Portugal's innovation output performance. However, caution must be taken when interpreting this results, since, as suggested by Liu and Zou (2008), different kinds of FDI might have differentiated effects on Portugal's innovation performance. Another area where Portugal stands behind the Eurozone is Infrastructure. Results suggest that Ecological Sustainability has a 
Table 11. Estimated impact of Portugal's convergence on the Knowledge Absorption sub-pillar with the Eurozone average and top performer

\begin{tabular}{cccc}
\hline Variable & $\begin{array}{c}\text { Estimated coefficient for Knowledge } \\
\text { Absorption }\end{array}$ & $\begin{array}{c}\text { Impact of convergence to the } \\
\text { Eurozone average }\end{array}$ & $\begin{array}{c}\text { Impact of convergence to the top } \\
\text { Eurozone performer (Netherlands) }\end{array}$ \\
\hline O6 (Eurozone) & 0.228 & 1.608 & 5.263 \\
\hline O7 (Eurozone) & 0.195 & 1.376 & 4.502 \\
\hline
\end{tabular}

I. Source: Own calculations.

Note: 06: Knowledge and technology outputs; 07: Creative outputs.

positive effect on Knowledge and Technology Outputs, hence, improving Portugal's environmental performance, as well as having more firms with ISO 14001 certificates, could result in higher innovation outputs. Regarding negative relationships found, further research is needed to understand their causes before implications can be drawn.

\section{CONCLUSIONS}

With this paper we sought to understand which innovation inputs had a greater contribution to innovative outputs. In an effort to derive policy implication for Portugal, we narrowed our analysis to a group of countries that share innovation policies and regulations, as well their national currencies, with Portugal, the Eurozone. To that end, we have adopted the framework provided by the Global Innovation Index, due to its clear distinction between innovation inputs and outputs, and, acknowledging methodological limitations induced by its own cross-sectional nature, we have developed our own panel data version (DuCa framework).

Overall, results suggest some surprising negative relationships between Institutions, Human Capital and Research and innovation outputs. Such results should be taken with some caution, since those are areas where investments tend to require some years to pay off, as is the case of institutional change, education and R\&D. Furthermore, Goedhuys et al. (2016) suggest that corruption can take the role of "grease in the wheels" when institutional obstacles are encountered, being otherwise an impediment to firm's innovation in sound business environments. Positive relationships have also been found, namely in Business Sophistication area, which revealed to be stronger when analysing Eurozone alone. Further analyses revealed that those effects came essentially from areas such as the imports of high-tech goods, ICT services, and knowledge, as well as the presence of researchers in businesses and inward FDI. This suggest that the overall Knowledge Absorption of countries in the Eurozone is key in determining their innovative readiness.

Therefore, we argue that policies directed at improving domestic firms' knowledge absorption capacity are likely to enhance Portugal's innovative outputs, especially benefiting from the convergence to average Eurozone levels.

\section{Limitations and Future Research}

As with every research, our study has its limitations which ought to be acknowledged. The use of an index could be, in itself, a limitation. Nonetheless, we consider it a solid indicator of national innovativeness, since it blends hard data with experts' opinions on a number of issues. Also, the GII is developed by some of the most important business and economics schools in cooperation with major international organisations.

The limited time period available impedes a longer analysis of the influence of certain variables, which we believe could have their impact felt further down the road. This limitation could be of extreme importance regarding the negative effects found throughout the paper, since investments in certain areas, such as education, $R \& D$, or public infrastructures, might require several years to attain the desired outcome. As such, further research is necessary to explore the causes of negative relationships between innovation inputs and outputs found in this paper.

Another possibly relevant constraint is the absence of control variables, commonly found in this type of empirical analyses (e.g. Martins and Veiga, 2018). However, the indicators used in the construction of this index already contemplate the vast majority of controls used in the literature.

Lastly, research is needed regarding the most significant results of this study, the impact of Knowledge Absorption on both innovation outputs. Notwithstanding the other indicators relating to imports of goods, services, and knowledge, and the presence of researchers in businesses, we consider that inward FDI plays a major role in the innovative capacity of a country, mainly due to its dual effect on domestic firms: first, by increasing the competition in the local market, domestic firms tend to innovate to maintain their market position (Bertschek, 1995; Blind and Jungmittag, 2004); and second, different types of FDI could have differentiated effects on domestic firms capacity to innovate (Liu and Zou, 2008). Owing to the latter effect, Liu and Zou (2008) found that greenfield R\&D FDI presented both intra- and inter-industry spillovers, while mergers and acquisitions produced only inter-industry spillovers. To derive more fine-grained policy implication to Portugal, one should rely on inward FDI data at the firm level, thus being able to control other firm's factors that cannot be measured at the country level.

\section{ACKNOWLEDGEMENTS}

The authors are grateful to the referees and the editor-in-chief for insightful comments and suggestions. This work has been funded by national funds through FCT - Fundação para a Ciência e a Tecnologia, I.P., Project UIDB/05037/2020. 


\section{REFERENCES}

Abel, J. R. and Deitz, R. (2012). Do colleges and universities increase their region's human capital? Journal of Economic Geography, 12(3), 667-691. https://doi.org/10.1093/jeg/lbr020

Alfantookh, A. and Bakry, S. H. (2015). Investigation of the state of innovation in the Gulf Cooperation Council countries: Looking ahead. Computers in Human Behavior, 48, 626-636. https://doi.org/10.1016/j.chb.2014.11.101

Amore, M. D., Schneider, C. and Žaldokas, A. (2013). Credit supply and corporate innovation. Journal of Financial Economics, 109(3), 835-855. https://doi.org/10.1016/j.jfineco.2013.04.006

Archibugi, D. and Coco, A. (2004). A new indicator of technological capabilities for developed and developing countries (ArCo). World Development, 32(4), 629-654. https://doi.org/10.1016/j.worlddev.2003.10.008

Archibugi, D., Denni, M. and Filippetti, A. (2009). The technological capabilities of nations: The state of the art of synthetic indicators. Technological Forecasting and Social Change, 76(7), 917-931. https://doi.org/10.1016/j.techfore.2009.01.002

Arendt, L. and Grabowski, W. (2017). Innovations, ICT and ICT-driven labour productivity in Poland. Economics of Transition, 25(4), 723-758. https://doi.org/10.1111/ecot.12135

Baltagi, B. H. (2015). Econometric Analysis of Panel Data (5 $5^{\text {th }}$ ed.). Chichester: John Wiley \& Sons.

Barragán-Ocaña, A., Reyes-Ruiz, G., Olmos-Peña, S. and Gómez-Viquez, H. (2020). Approach to the identification of an alternative technological innovation index. Scientometrics, 122(1), 23-45. https://doi.org/10.1007/s11192-019-03292-9

Beck, T. and Levine, R. (2002). Stock markets, banks, and growth: Panel evidence (NBER working paper No. 9082). https://doi.org/10.3386/w9082

Becker, W., Saisana, M., Paruolo, P. and Vandecasteele, I. (2018). Weights and importance in composite indicators: Closing the gap. Ecological Indicators, 80, 12-22.

Bendapudi, N., Zhan, S. and Hong, Y. (2018). Cultural values differentially moderate the benefits of basic education on two types of national innovation outputs. Journal of Cross-Cultural Psychology, 49(2), $199-222$. https://doi.org/10.1177/0022022116650259

Bertschek, I. (1995). Product and process innovation as a response to increasing imports and foreign direct investment. The Journal of Industrial Economics, 43(4), 341-357. https://doi.org/10.2307/2950548

Bilbao-Osorio, B. and Rodriguez-Pose, A. (2004). From R\&D to innovation and economic growth in the EU. Growth and Change, 35(4), 434-455. https://doi.org/10.1111/j.1468-2257.2004.00256.x

Blind, K. and Jungmittag, A. (2004). Foreign direct investment, imports and innovations in the service industry. Review of Industrial Organization, 25(2), 205-227. https://doi.org/10.1007/s11151-004-3537-x

Borrás, S. and Laatsit, M. (2019). Towards system oriented innovation policy evaluation? Evidence from EU28 member states. Research Policy, 48(1), 312-321. https://doi.org/10.1016/j.respol.2018.08.020

Cainelli, G., D’Amato, A. and Mazzanti, M. (2020). Resource efficient eco-innovations for a circular economy: Evidence from EU firms. Research Policy, 49(1), 103827. https://doi.org/10.1016/j.respol.2019.103827

Cerqueiro, G., Hegde, D., Penas, M. F. and Seamans, R. C. (2017). Debtor rights, credit supply, and innovation. Management Science, 63(10), 3311-3327. https://doi.org/10.1287/mnsc.2016.2509

Cohen, W. M. and Levinthal, D. A. (1990). Absorptive capacity: A new perspective on learning and innovation. Administrative Science Quarterly, 35, 128-152.

Cornell University, INSEAD and WIPO. (2013). The global innovation index 2013: The local dynamics of innovation (S. Dutta \& B. Lanvin (Eds.)). Geneva, Ithaca and Fontainebleau.

Cornell University, INSEAD and WIPO. (2014). The global innovation index 2014: The human factor in innovation (S. Dutta, B. Lanvin and S. Wunsch-Vincent (Eds.)). Geneva, Ithaca and Fontainebleau.

Cornell University, INSEAD and WIPO. (2015). The global innovation index 2015: Effective innovation policies for development (S. Dutta, B. Lanvin and S. Wunsch-Vincent (Eds.)). Geneva, Ithaca and Fontainebleau.

Cornell University, INSEAD and WIPO. (2016). The global innovation index 2016: Winning with global innovation (S. Dutta, B. Lanvin and S. Wunsch-Vincent (Eds.)). Geneva, Ithaca and Fontainebleau.

Cornell University, INSEAD and WIPO. (2017). The global innovation index 2017: Innovation feeding the world (S. Dutta, B. Lanvin and S. Wunsch-Vincent (Eds.)). Geneva, Ithaca and Fontainebleau.

Cornell University, INSEAD and WIPO. (2018). The global innovation index 2018: Energizing the world with innovation (S. Dutta, B. Lanvin and S. Wunsch-Vincent (Eds.)). Geneva, Ithaca and Fontainebleau.

Cottrell, A. F. and Lucchetti, R. J. (2009). Gretl - Gnu regression, econometrics and time-series. (computer software). Available at: http://gretl.sourceforge.net/

Crespo, N. F. and Crespo, C. F. (2016). Global innovation index: Moving beyond the absolute value of ranking with a fuzzy-set analysis. Journal of Business Research, 69(11), 5265-5271. https://doi.org/10.1016/j.jbusres.2016.04.123

Cuevas-Vargas, H., Estrada, S. and Larios-Gómez, E. (2016). The effects of ICTs as innovation facilitators for a greater business performance. Evidence from Mexico. Procedia Computer Science, 91, 47-56. https://doi.org/10.1016/j.procs.2016.07.040 
Díez-Vial, I. and Montoro-Sánchez, Á. (2016). How knowledge links with universities may foster innovation: The case of a science park. Technovation, 50-51, 41-52. https://doi.org/10.1016/j.technovation.2015.09.001

Dutta, S. (Ed.). (2009). Global Innovation Index 2008-2009.

Dutta, S., INSEAD and Caulkin, S. (2007). The world's top innovators. World Business, 26-37.

Edquist, C. (2006). Systems of innovation: Perspectives and challenges. In J. Fagerberg, D. C. Mowery and R. R. Nelson (Eds.), The Oxford Handbook of Innovation (pp. 181-208). Oxford, UK: Oxford University Press. https://doi.org/10.1093/oxfordhb/9780199286805.003.0007

Edquist, C., Zabala-Iturriagagoitia, J. M., Barbero, J. and Zofío, J. L. (2018). On the meaning of innovation performance: Is the synthetic indicator of the innovation union scoreboard flawed? Research Evaluation, 27(3), $196-211$. https://doi.org/10.1093/reseval/rvy011

Erciş, A. and Ünalan, M. (2016). Innovation: A comparative case study of Turkey and South Korea. Procedia - Social and Behavioral Sciences, 235, 701-708. https://doi.org/10.1016/j.sbspro.2016.11.071

European Comission. (2018). European Innovation Scoreboard 2018.

Fagerberg, J. and Srholec, M. (2008). National innovation systems, capabilities and economic development. Research Policy, 37(9), 1417-1435. https://doi.org/10.1016/j.respol.2008.06.003

Fagerberg, J., Srholec, M. and Verspagen, B. (2010). Innovation and economic development. In B. H. Hall \& N. Rosenberg (Eds.), Handbook of the Economics of Innovation (Vol. 2, pp. 833-872). Elsevier B.V. https://doi.org/10.1016/S0169-7218(10)02004-6

Freeman, C. (1987). Technology policy and economic performance: Lessons from Japan. London: Pinter.

Freeman, C. (1995). The 'National System of Innovation' in historical perspective. Cambridge Journal of Economics, 19(1), 5-24. https://doi.org/10.1093/oxfordjournals.cje.a035309

Furman, J. L., Porter, M. E. and Stern, S. (2002). The determinants of national innovative capacity. Research Policy, 31(6), $899-933$. https://doi.org/10.1016/S0048-7333(01)00152-4

Gault, F. (2018). Defining and measuring innovation in all sectors of the economy. Research Policy, 47(3), 617-622. https://doi.org/10.1016/j.respol.2018.01.007

Gkypali, A., Arvanitis, S. and Tsekouras, K. (2018). Absorptive capacity, exporting activities, innovation openness and innovation performance: A SEM approach towards a unifying framework. Technological Forecasting and Social Change, 132, 143-155. https://doi.org/10.1016/j.techfore.2018.01.025

Godin, B. (2007). Science, accounting and statistics: The input-output framework. Research Policy, 36(9), $1388-1403$. https://doi.org/10.1016/j.respol.2007.06.002

Goedhuys, M., Mohnen, P. and Taha, T. (2016). Corruption, innovation and firm growth: Firm-level evidence from Egypt and Tunisia. Eurasian Business Review, 6(3), 299-322. https://doi.org/10.1007/s40821-016-0062-4

Grupp, H. and Schubert, T. (2010). Review and new evidence on composite innovation indicators for evaluating national performance. Research Policy, 39(1), 67-78. https://doi.org/10.1016/j.respol.2009.10.002

Hsiao, C. (2007). Panel data analysis-advantages and challenges. TEST, 16(1), 1-22. https://doi.org/10.1007/s11749-007-0046-X

Hsu, P.-H., Tian, X. and Xu, Y. (2014). Financial development and innovation: Cross-country evidence. Journal of Financial Economics, 112(1), 116-135. https://doi.org/10.1016/j.jfineco.2013.12.002

Iqbal, A. (2011). Creativity and innovation in Saudi Arabia: An overview. Innovation: Management, Policy \& Practice, 13(3), 376-390. https://doi.org/10.5172/impp.2011.13.3.376

Khan, S. A. R. and Yu, Z. (2019). Strategic supply chain management. Cham: Springer International Publishing. https://doi.org/10.1007/978-3-030-15058-7

Khedhaouria, A. and Thurik, R. (2017). Configurational conditions of national innovation capability: A fuzzy set analysis approach. Technological Forecasting and Social Change, 120, 48-58. https://doi.org/10.1016/j.techfore.2017.04.005

King, R. G. and Levine, R. (1993). Finance and growth: Schumpeter might be right. Quarterly Journal of Economics, 108(3), $717-737$.

Kortum, S. and Lerner, J. (2000). Assessing the contribution of venture capital to innovation. RAND Journal of Economics, 31(4), 674-692.

Kuhlman, C., Ramamurthy, K. N., Sattigeri, P., Lozano, A. C., Cao, L., Reddy, C., Mojsilovic, A. and Varshney, K. R. (2017). How to foster innovation: A data-driven approach to measuring economic competitiveness. IBM Journal of Research and Development, 61(6), 11:1-11:12. https://doi.org/10.1147/JRD.2017.2741820

La Porta, R., Lopez-de-Silanes, F., Shleifer, A. and Vishny, R. W. (1998). Law and finance. Journal of Political Economy, 106(6), 11131155. https://doi.org/10.1086/250042

Liu, X. and Zou, H. (2008). The impact of greenfield FDI and mergers and acquisitions on innovation in Chinese high-tech industries. Journal of World Business, 43(3), 352-364. https://doi.org/10.1016/j.jwb.2007.11.004

Love, J. H. and Mansury, M. A. (2007). External linkages, R\&D and innovation performance in US business services. Industry \& Innovation, 14(5), 477-496. https://doi.org/10.1080/13662710701711380

Lundvall, B. (Ed.). (1992). National systems of innovation: Towards a theory of innovation and interactive learning. London: Pinter. 
Maietta, O. W. (2015). Determinants of university-firm R\&D collaboration and its impact on innovation: A perspective from a lowtech industry. Research Policy, 44(7), 1341-1359. https://doi.org/10.1016/j.respol.2015.03.006

Martins, J. and Veiga, L. (2018). Innovations in digital government as business facilitators: Implications for Portugal (GEE paper No. 97). Available at: https://econpapers.repec.org/RePEc:mde:wpaper:0097

Marxt, C. and Brunner, C. (2013). Analyzing and improving the national innovation system of highly developed countries - The case of Switzerland. Technological Forecasting and Social Change, 80(6), $1035-1049$. https://doi.org/10.1016/j.techfore.2012.07.008

Nasierowski, W. and Arcelus, F. J. (1999). Interrelationships among the elements of national innovation systems: A statistical evaluation. European Journal of Operational Research, 119(2), 235-253. https://doi.org/10.1016/S0377-2217(99)00128-9

Nelson, A., Earle, A., Howard-Grenville, J., Haack, J. and Young, D. (2014). Do innovation measures actually measure innovation? Obliteration, symbolic adoption, and other finicky challenges in tracking innovation diffusion. Research Policy, 43(6), 927-940. https://doi.org/10.1016/j.respol.2014.01.010

Nelson, R. R. (Ed.). (1993). National innovation systems: A comparative analysis. New York: Oxford University Press.

North, D. C. (1994). Economic performance through time. American Economic Review, 84(3), 359-368.

OECD. (2017). OECD Science, Technology and Industry Scoreboard 2017: The digital transformation. Paris: OECD Publishing. https://doi.org/10.1787/9789264268821-en

Pençe, I.., Kalkan, A. and Çeşmeli, M. Ş. (2019). Estimation of the country ranking scores on the global innovation index 2016 using the artificial neural network method. International Journal of Innovation and Technology Management, 16(04), 1940007. https://doi.org/10.1142/S0219877019400078

Porter, M. E. and Stern, S. (1999). The new challenge to America's prosperity: Findings from the innovation index. Washington, DC: Council on Competitiveness.

Silve, F. and Plekhanov, A. (2015). Institutions, innovation and growth: Cross-country evidence (EBRD working paper No. 177).

Smith, K. (2006). Measuring innovation. In J. Fagerberg, D. C. Mowery and R. R. Nelson (Eds.), The Oxford Handbook of Innovation (pp. 148-177). Oxford, UK: Oxford University Press. https://doi.org/10.1093/oxfordhb/9780199286805.003.0006

Sohn, S. Y., Kim, D. H. and Jeon, S. Y. (2016). Re-evaluation of global innovation index based on a structural equation model. Technology Analysis \& Strategic Management, 28(4), 492-505. https://doi.org/10.1080/09537325.2015.1104412

Suseno, Y., Standing, C., Kiani-Mavi, R. and Jackson, P. (2018). National innovation performance: The role of human capital and social capital. Innovation: The European Journal of Social Science Research, 1-15. https://doi.org/10.1080/13511610.2018.1536536

Tebaldi, E. and Elmslie, B. (2013). Does institutional quality impact innovation? Evidence from cross-country patent grant data. Applied Economics, 45(7), 887-900. https://doi.org/10.1080/00036846.2011.613777

Teixeira, A. A. C. (2014). Evolution, roots and influence of the literature on national systems of innovation: A bibliometric account. Cambridge Journal of Economics, 38(1), 181-214. https://doi.org/10.1093/cje/bet022

UN. (2015). Transforming our world: The 2030 Agenda for Sustainable Development. United Nations.

Van Hiel, A., Van Assche, J., De Cremer, D., Onraet, E., Bostyn, D., Haesevoets, T. and Roets, A. (2018). Can education change the world? Education amplifies differences in liberalization values and innovation between developed and developing countries. PLOS ONE, 13(6), 1-8. https://doi.org/10.1371/journal.pone.0199560

Wooldridge, J. M. (2016). Introdutory econometrics: A modern approach (6 $6^{\text {th }}$ ed.). Boston, MA: Cengage Learning.

Zabala-Iturriagagoitia, J. M., Voigt, P., Gutiérrez-Gracia, A. and Jiménez-Sáez, F. (2007). Regional Innovation Systems: How to Assess Performance. Regional Studies, 41(5), 661-672. https://doi.org/10.1080/00343400601120270 


\section{APPENDIX}

Table A1. Variables used, codes, definitions, sources and time-series

\begin{tabular}{|c|c|c|c|c|}
\hline Code & Indicator & Definition & $\begin{array}{l}\text { Source } \\
\end{array}$ & Period \\
\hline 111 & $\begin{array}{l}\text { Political stability and absence } \\
\text { of violence / terrorism }\end{array}$ & $\begin{array}{l}\text { Political stability and absence of violence / } \\
\text { terrorism index }\end{array}$ & $\begin{array}{c}\text { Global Innovation Index } \\
\text { (https://www.globalinnovationindex.org/analysis-indicator) }\end{array}$ & $2013-2018$ \\
\hline 112 & Government effectiveness & Government effectiveness index & $\begin{array}{c}\text { Global Innovation Index } \\
\text { (https://www.globalinnovationindex.org/analysis-indicator) }\end{array}$ & $2013-2018$ \\
\hline 121 & Regulatory quality & Regulatory quality index & $\begin{array}{c}\text { Global Innovation Index } \\
\text { (https://www.globalinnovationindex.org/analysis-indicator) }\end{array}$ & $2013-2018$ \\
\hline 122 & Rule of law & Rule of law index & $\begin{array}{c}\text { Global Innovation Index } \\
\text { (https://www.globalinnovationindex.org/analysis-indicator) }\end{array}$ & $2013-2018$ \\
\hline 123 & Cost of redundancy dismissal & $\begin{array}{l}\text { Sum of notice period and severance pay for } \\
\text { redundancy dismissal (in salary weeks, } \\
\text { averages for worker with } 1,5,10 \text { years of } \\
\text { tenure, with a minimum threshold of } 8 \text { weeks) }\end{array}$ & $\begin{array}{c}\text { Global Innovation Index } \\
\text { (https://www.globalinnovationindex.org/analysis-indicator) }\end{array}$ & $2013-2018$ \\
\hline 131 & Ease of starting a business & Ease of starting a business (distance to frontier) & $\begin{array}{c}\text { Global Innovation Index } \\
\text { (https://www.globalinnovationindex.org/analysis-indicator) }\end{array}$ & $2013-2018$ \\
\hline 132 & Ease of resolving insolvency & $\begin{array}{l}\begin{array}{l}\text { Ease of resolving insolvency (distance to } \\
\text { frontier) }\end{array} \\
\end{array}$ & $\begin{array}{c}\text { Global Innovation Index } \\
\text { (https://www.globalinnovationindex.org/analysis-indicator) }\end{array}$ & $2013-2018$ \\
\hline 133 & Ease of paying taxes & Ease of paying taxes (distance to frontier) & $\begin{array}{c}\text { Global Innovation Index } \\
\text { (https://www.globalinnovationindex.org/analysis-indicator) }\end{array}$ & $2013-2017$ \\
\hline 211 & Expenditure on education & $\begin{array}{l}\text { Government expenditure on education (\% of } \\
\text { GDP) }\end{array}$ & $\begin{array}{l}\text { UNESCO Institute for Statistics } \\
\text { (http://data.uis.unesco.org/\#) }\end{array}$ & $2011-2016$ \\
\hline 212 & $\begin{array}{l}\text { Initial government funding per } \\
\text { secondary student }\end{array}$ & $\begin{array}{l}\text { Initial government funding per secondary } \\
\text { student (\% of GDP per capita) }\end{array}$ & $\begin{array}{l}\text { UNESCO Institute for Statistics } \\
\text { (http://data.uis.unesco.org/\#) }\end{array}$ & $2011-2016$ \\
\hline 213 & School life expectancy & $\begin{array}{c}\text { School life expectancy, primary to tertiary } \\
\text { education, both sexes (years) }\end{array}$ & $\begin{array}{c}\text { Global Innovation Index } \\
\text { (https://www.globalinnovationindex.org/analysis-indicator) }\end{array}$ & $2013-2018$ \\
\hline 214 & $\begin{array}{l}\text { Assessment in reading, } \\
\text { mathematics, and science }\end{array}$ & $\begin{array}{l}\text { PISA average scales in reading, mathematics, } \\
\text { and science }\end{array}$ & $\begin{array}{c}\text { Global Innovation Index } \\
\text { (https://www.globalinnovationindex.org/analysis-indicator) }\end{array}$ & $2013-2018$ \\
\hline 215 & Pupil-teacher ratio, secondary & Pupil-teacher ratio, secondary & $\begin{array}{c}\text { Global Innovation Index } \\
\text { (https://www.globalinnovationindex.org/analysis-indicator) }\end{array}$ & $2013-2018$ \\
\hline 221 & Tertiary enrolment & School enrolment, tertiary (\% gross) & $\begin{array}{c}\text { Global Innovation Index } \\
\text { (https://www.globalinnovationindex.org/analysis-indicator) }\end{array}$ & $2013-2018$ \\
\hline 222 & $\begin{array}{l}\text { Graduates in science and } \\
\text { engineering }\end{array}$ & $\begin{array}{c}\text { Tertiary graduates in science, engineering, } \\
\text { manufacturing, and construction (\% of total } \\
\text { tertiary graduates) }\end{array}$ & $\begin{array}{c}\text { Global Innovation Index } \\
\text { (https://www.globalinnovationindex.org/analysis-indicator) }\end{array}$ & $2013-2018$ \\
\hline 223 & Tertiary-level inbound mobility & Tertiary-level inbound mobility rate (\%) & $\begin{array}{c}\text { Global Innovation Index } \\
\text { (https://www.globalinnovationindex.org/analysis-indicator) }\end{array}$ & $2013-2018$ \\
\hline 231 & Researchers & $\begin{array}{l}\text { Researchers, full-time equivalent (FTE) (per } \\
\text { million inhabitants) }\end{array}$ & $\begin{array}{l}\text { UNESCO Institute for Statistics } \\
\text { (http://data.uis.unesco.org/\#) }\end{array}$ & $2011-2016$ \\
\hline 232 & $\begin{array}{l}\text { Gross expenditure on R\&D } \\
\text { (GERD) }\end{array}$ & GERD: Gross expenditure on R\&D (\% of GDP) & $\begin{array}{c}\text { Global Innovation Index } \\
\text { (https://www.globalinnovationindex.org/analysis-indicator) }\end{array}$ & $2013-2018$ \\
\hline 233 & $\begin{array}{l}\text { QS university ranking average } \\
\text { score of top } 3 \text { universities }\end{array}$ & $\begin{array}{c}\text { Average score of the top } 3 \text { universities at the QS } \\
\text { world university ranking }\end{array}$ & $\begin{array}{c}\text { Global Innovation Index } \\
\text { (https://www.globalinnovationindex.org/analysis-indicator) }\end{array}$ & $2013-2018$ \\
\hline 311 & ICT access & ICT access index & $\begin{array}{c}\text { Global Innovation Index } \\
\text { (https://www.globalinnovationindex.org/analysis-indicator) }\end{array}$ & $2013-2018$ \\
\hline 312 & ICT use & ICT use index & $\begin{array}{c}\text { Global Innovation Index } \\
\text { (https://www.globalinnovationindex.org/analysis-indicator) }\end{array}$ & $2013-2018$ \\
\hline 313 & Government's online service & Government's online service index & $\begin{array}{c}\text { Global Innovation Index } \\
\text { (https://www.globalinnovationindex.org/analysis-indicator) }\end{array}$ & $2013-2018$ \\
\hline 314 & Online e-participation & E-participation index & $\begin{array}{c}\text { Global Innovation Index } \\
\text { (https://www.globalinnovationindex.org/analysis-indicator) }\end{array}$ & $2013-2018$ \\
\hline 321 & Electricity output & Electricity output (kWh per capita) & $\begin{array}{c}\text { Global Innovation Index } \\
\text { (https://www.globalinnovationindex.org/analysis-indicator) }\end{array}$ & $2013-2018$ \\
\hline 322 & Logistics performance & Logistics Performance Index & $\begin{array}{c}\text { Global Innovation Index } \\
\text { (https://www.globalinnovationindex.org/analysis-indicator) }\end{array}$ & $2013-2018$ \\
\hline 323 & Gross capital formation & Gross capital formation (\% of GDP) & $\begin{array}{c}\text { Global Innovation Index } \\
\text { (https://www.globalinnovationindex.org/analysis-indicator) }\end{array}$ & $2013-2018$ \\
\hline 331 & GDP per unit of energy use & $\begin{array}{c}\text { GDP per unit of energy use (2010 PPP\$ per kg of } \\
\text { oil equivalent) }\end{array}$ & $\begin{array}{c}\text { Global Innovation Index } \\
\text { (https://www.globalinnovationindex.org/analysis-indicator) }\end{array}$ & $2013-2018$ \\
\hline 332 & Environmental performance & Environmental Performance Index & $\begin{array}{c}\text { Global Innovation Index } \\
\text { (https://www.globalinnovationindex.org/analysis-indicator) }\end{array}$ & $2013-2018$ \\
\hline 333 & $\begin{array}{l}\text { ISO } 14001 \text { environmental } \\
\text { certificates }\end{array}$ & $\begin{array}{l}\text { ISO } 14001 \text { Environmental management } \\
\text { systems - Requirements with guidance for use: } \\
\text { Number of certificates issued (per bn PPP\$ } \\
\text { GDP) }\end{array}$ & $\begin{array}{l}\text { Global Innovation Index } \\
\text { (https://www.globalinnovationindex.org/analysis-indicator) }\end{array}$ & $2013-2018$ \\
\hline 411 & Ease of getting credit & Ease of getting credit (distance to frontier) & $\begin{array}{c}\text { Global Innovation Index } \\
\text { (https://www.globalinnovationindex.org/analysis-indicator) }\end{array}$ & $2013-2018$ \\
\hline 412 & $\begin{array}{c}\text { Domestic credit to private } \\
\text { sector }\end{array}$ & Domestic credit to private sector (\% of GDP) & $\begin{array}{c}\text { Global Innovation Index } \\
\text { (https://www.globalinnovationindex.org/analysis-indicator) }\end{array}$ & $2013-2018$ \\
\hline 413 & $\begin{array}{l}\text { Microfinance institutions' gross } \\
\text { loan portfolio }\end{array}$ & $\begin{array}{l}\text { Microfinance institutions: Gross loan portfolio } \\
\text { (\% of GDP) }\end{array}$ & $\begin{array}{c}\text { Global Innovation Index } \\
\text { (https://www.globalinnovationindex.org/analysis-indicator) }\end{array}$ & $2013-2018$ \\
\hline 421 & $\begin{array}{l}\text { Ease of protecting minority } \\
\text { investors }\end{array}$ & $\begin{array}{l}\text { Ease of protecting minority investors (distance } \\
\text { to frontier) }\end{array}$ & $\begin{array}{c}\text { Global Innovation Index } \\
\text { (https://www.globalinnovationindex.org/analysis-indicator) }\end{array}$ & $2013-2018$ \\
\hline
\end{tabular}


Table A1 (continued). Variables used, codes, definitions, sources and time-series

\begin{tabular}{|c|c|c|c|c|}
\hline Code & Indicator & Definition & Source & Period \\
\hline 422 & Market capitalisation & $\begin{array}{l}\text { Market capitalisation of listed domestic } \\
\text { companies (\% of GDP) }\end{array}$ & $\begin{array}{c}\text { World Bank, World Development Indicators } \\
\text { (https://databank.worldbank.org/data/source/world- } \\
\text { development-indicators) }\end{array}$ & $2012-2017$ \\
\hline 423 & Total value of stocks traded & Stocks traded, total value (\% of GDP) & $\begin{array}{c}\text { World Bank, World Development Indicators } \\
\text { (https://databank.worldbank.org/data/source/world- } \\
\text { development-indicators) }\end{array}$ & $2012-2017$ \\
\hline 424 & Venture capital deals & $\begin{array}{l}\text { Venture capital per investment location: } \\
\text { Number of deals (per bn PPP\$ GDP) }\end{array}$ & $\begin{array}{c}\text { Global Innovation Index } \\
\text { (https://www.globalinnovationindex.org/analysis-indicator) }\end{array}$ & $2013-2018$ \\
\hline 431 & $\begin{array}{l}\text { Applied tariff rate, weighted } \\
\text { mean }\end{array}$ & $\begin{array}{c}\text { Tariff rate, applied, weighted mean, all } \\
\text { products (\%) }\end{array}$ & $\begin{array}{c}\text { Global Innovation Index } \\
\text { (https://www.globalinnovationindex.org/analysis-indicator) }\end{array}$ & $2013-2018$ \\
\hline 432 & Intensity of local competition & $\begin{array}{c}\text { Average answer to the survey question: In your } \\
\text { country, how intense is the competition in the } \\
\text { local markets? [ } 1=\text { not intense at all; } 7= \\
\text { extremely intense] }\end{array}$ & $\begin{array}{l}\text { Global Innovation Index } \\
\text { (https://www.globalinnovationindex.org/analysis-indicator) }\end{array}$ & $2013-2018$ \\
\hline 433 & Domestic market scale & $\begin{array}{l}\text { Domestic market as measured by GDP, PPP } \\
\text { (current international \$) }\end{array}$ & $\begin{array}{c}\text { World Bank, World Development Indicators } \\
\text { (https://databank.worldbank.org/data/source/world- } \\
\text { development-indicators) }\end{array}$ & $2012-2017$ \\
\hline 511 & $\begin{array}{l}\text { Employment in knowledge- } \\
\text { intensive services }\end{array}$ & $\begin{array}{l}\text { Employment in knowledge intensive services } \\
\text { (\% of workforce) }\end{array}$ & $\begin{array}{c}\text { International Labour Organization ILOSTAT } \\
\text { (https://www.ilo.org/ilostat/) }\end{array}$ & $2012-2017$ \\
\hline 512 & Firms offering formal training & Firms offering formal training ( $\%$ of firms) & $\begin{array}{c}\text { Global Innovation Index } \\
\text { (https://www.globalinnovationindex.org/analysis-indicator) }\end{array}$ & $2013-2018$ \\
\hline 513 & $\begin{array}{l}\text { GERD performed by business } \\
\text { enterprise }\end{array}$ & $\begin{array}{l}\text { GERD: Performed by business enterprise (\% of } \\
\text { GDP) }\end{array}$ & $\begin{array}{l}\text { UNESCO Institute for Statistics } \\
\text { (http://data.uis.unesco.org/\#) }\end{array}$ & $2011-2016$ \\
\hline 514 & $\begin{array}{l}\text { GERD financed by business } \\
\text { enterprise }\end{array}$ & $\begin{array}{c}\text { GERD: Financed by business enterprise (\% of } \\
\text { total GERD) }\end{array}$ & $\begin{array}{l}\text { UNESCO Institute for Statistics } \\
\text { (http://data.uis.unesco.org/\#) }\end{array}$ & $2011-2016$ \\
\hline 515 & $\begin{array}{l}\text { Females employed with } \\
\text { advanced degrees }\end{array}$ & $\begin{array}{l}\text { Females employed with advanced degrees, } \% \\
\text { of total employed ( } 25+\text { years old) }\end{array}$ & $\begin{array}{c}\text { International Labour Organization ILOSTAT } \\
\text { (https://www.ilo.org/ilostat/) }\end{array}$ & $2012-2017$ \\
\hline 521 & $\begin{array}{l}\text { University / industry research } \\
\text { collaboration }\end{array}$ & $\begin{array}{l}\text { Average answer to the survey question: In your } \\
\text { country, to what extent do businesses and } \\
\text { universities collaborate on research and } \\
\text { development (R\&D)? [ } 1 \text { = do not collaborate at } \\
\text { all; } 7 \text { = collaborate extensively] }\end{array}$ & $\begin{array}{l}\text { Global Innovation Index } \\
\text { (https://www.globalinnovationindex.org/analysis-indicator) }\end{array}$ & $2013-2018$ \\
\hline 522 & State of cluster development & $\begin{array}{l}\text { in the economy: In your country, how } \\
\text { widespread are well-developed and deep } \\
\text { clusters (geographic concentrations of firms, } \\
\text { suppliers, producers of related products and } \\
\text { services, and specialized institutions in a } \\
\text { particular field)? [ } 1 \text { = non-existent; } 7 \text { = } \\
\text { widespread in many fields] }\end{array}$ & $\begin{array}{c}\text { Global Innovation Index } \\
\text { (https://www.globalinnovationindex.org/analysis-indicator) }\end{array}$ & $2013-2018$ \\
\hline 523 & GERD financed by abroad & GERD: Financed by abroad (\% of total GERD) & $\begin{array}{c}\text { Global Innovation Index } \\
\text { (https://www.globalinnovationindex.org/analysis-indicator) }\end{array}$ & $2013-2018$ \\
\hline 524 & $\begin{array}{l}\text { Joint venture / strategic } \\
\text { alliance deals } \\
\end{array}$ & $\begin{array}{l}\text { Joint ventures / strategic alliances: Number of } \\
\text { deals, fractional counting (per bn PPP\$ GDP) }\end{array}$ & $\begin{array}{c}\text { Global Innovation Index } \\
\text { (https://www.globalinnovationindex.org/analysis-indicator) } \\
\end{array}$ & $2013-2018$ \\
\hline 531 & Intellectual property payments & $\begin{array}{c}\text { Charges for use of intellectual property n.i.e., } \\
\text { payments (\% of total trade) }\end{array}$ & World Trade Organization (https://data.wto.org/) & $2012-2017$ \\
\hline 532 & High-tech imports & High-tech net imports ( $\%$ of total trade) & $\begin{array}{l}\text { United Nations Comtrade database } \\
\text { (https://comtrade.un.org/data/) }\end{array}$ & $2012-2017$ \\
\hline 533 & ICT services imports & $\begin{array}{l}\text { Telecommunications, computers, and } \\
\text { information services imports (\% of total trade) }\end{array}$ & World Trade Organization (https://data.wto.org/) & $2012-2017$ \\
\hline 534 & $\begin{array}{l}\text { Foreign direct investment net } \\
\text { inflows }\end{array}$ & $\begin{array}{l}\text { Foreign direct investment (FDI), net inflows (\% } \\
\text { of GDP) }\end{array}$ & $\begin{array}{c}\text { World Bank, World Development Indicators } \\
\text { (https://databank.worldbank.org/data/source/world- } \\
\text { development-indicators) }\end{array}$ & $2012-2017$ \\
\hline 535 & $\begin{array}{l}\text { Research talent in business } \\
\text { enterprise }\end{array}$ & Researchers in business enterprise (\%) & $\begin{array}{l}\text { UNESCO Institute for Statistics } \\
\text { (http://data.uis.unesco.org/\#) }\end{array}$ & $2011-2016$ \\
\hline 611 & Patent applications by origin & $\begin{array}{l}\text { Number of resident patent applications filed at } \\
\text { a given national or regional patent office (per } \\
\text { bn PPP\$ GDP) }\end{array}$ & $\begin{array}{c}\text { Global Innovation Index } \\
\text { (https://www.globalinnovationindex.org/analysis-indicator) }\end{array}$ & $2013-2018$ \\
\hline 612 & $\begin{array}{l}\text { PCT international applications } \\
\text { by origin }\end{array}$ & $\begin{array}{c}\text { Number of international patent applications } \\
\text { filed by residents at the Patent Cooperation } \\
\text { Treaty (per bn PPP\$ GDP) }\end{array}$ & $\begin{array}{c}\text { Global Innovation Index } \\
\text { (https://www.globalinnovationindex.org/analysis-indicator) }\end{array}$ & $2013-2018$ \\
\hline 613 & $\begin{array}{l}\text { Utility model applications by } \\
\text { origin }\end{array}$ & $\begin{array}{l}\text { Number of utility model applications filed by } \\
\text { residents at the national patent office (per bn } \\
\text { PPP\$ GDP) }\end{array}$ & $\begin{array}{c}\text { Global Innovation Index } \\
\text { (https://www.globalinnovationindex.org/analysis-indicator) }\end{array}$ & $2013-2018$ \\
\hline 614 & $\begin{array}{l}\text { Scientific and technical } \\
\text { publications }\end{array}$ & $\begin{array}{c}\text { Number of scientific and technical journal } \\
\text { articles (per bn PPP\$ GDP) }\end{array}$ & $\begin{array}{c}\text { Global Innovation Index } \\
\text { (https://www.globalinnovationindex.org/analysis-indicator) }\end{array}$ & $2013-2018$ \\
\hline 615 & Citable documents $\mathrm{H}$ index & $\begin{array}{c}\text { The } \mathrm{H} \text { index is the economy's number of } \\
\text { published articles }(\mathrm{H}) \text { that have received at } \\
\text { least } \mathrm{H} \text { citations }\end{array}$ & $\begin{array}{c}\text { Global Innovation Index } \\
\text { (https://www.globalinnovationindex.org/analysis-indicator) }\end{array}$ & $2013-2018$ \\
\hline 621 & $\begin{array}{c}\text { Growth rate of GDP per person } \\
\text { engaged }\end{array}$ & $\begin{array}{l}\text { Growth rate of GDP per person engaged } \\
\text { (constant 2011 PPP\$) }\end{array}$ & $\begin{array}{c}\text { Global Innovation Index } \\
\text { (https://www.globalinnovationindex.org/analysis-indicator) }\end{array}$ & $2013-2018$ \\
\hline 622 & New business density & $\begin{array}{l}\text { New business density (new registrations per } \\
\text { thousand population } 15-64 \text { years old) }\end{array}$ & $\begin{array}{c}\text { Global Innovation Index } \\
\text { (https://www.globalinnovationindex.org/analysis-indicator) }\end{array}$ & $2013-2018$ \\
\hline 623 & $\begin{array}{c}\text { Total computer software } \\
\text { spending }\end{array}$ & Total computer software spending (\% of GDP) & $\begin{array}{c}\text { Global Innovation Index } \\
\text { (https://www.globalinnovationindex.org/analysis-indicator) }\end{array}$ & $2013-2018$ \\
\hline
\end{tabular}


Table A1 (continued). Variables used, codes, definitions, sources and time-series

\begin{tabular}{|c|c|c|c|c|}
\hline Code & Indicator & Definition & Source & Period \\
\hline 624 & ISO 9001 quality certificates & $\begin{array}{l}\text { ISO } 9001 \text { Quality management systems- } \\
\text { Requirements: Number of certificates issued } \\
\text { (per bn PPP\$ GDP) }\end{array}$ & $\begin{array}{l}\text { Global Innovation Index } \\
\text { (https://www.globalinnovationindex.org/analysis-indicator) }\end{array}$ & $2013-2018$ \\
\hline 625 & $\begin{array}{l}\text { High-tech and medium-high- } \\
\text { tech output }\end{array}$ & $\begin{array}{l}\text { High-tech and medium-high-tech output (\% of } \\
\text { total manufactures output) }\end{array}$ & $\begin{array}{c}\text { Global Innovation Index } \\
\text { (https://www.globalinnovationindex.org/analysis-indicator) }\end{array}$ & $2013-2017$ \\
\hline 631 & Intellectual property receipts & $\begin{array}{l}\text { Charges for use of intellectual property n.i.e., } \\
\text { receipts (\% of total trade) }\end{array}$ & World Trade Organization (https://data.wto.org/) & $2012-2017$ \\
\hline 632 & High-tech exports & High-tech net exports (\% of total trade) & $\begin{array}{l}\text { United Nations Comtrade database } \\
\text { (https://comtrade.un.org/data/) }\end{array}$ & $2012-2017$ \\
\hline 633 & ICT services exports & $\begin{array}{c}\text { Telecommunications, computers, and } \\
\text { information services exports ( } \% \text { of total trade) }\end{array}$ & World Trade Organization (https://data.wto.org/) & $2012-2017$ \\
\hline 634 & $\begin{array}{l}\text { Foreign direct investment net } \\
\text { outflows }\end{array}$ & $\begin{array}{l}\text { Foreign direct investment (FDI), net outflows } \\
\qquad(\% \text { of GDP) }\end{array}$ & $\begin{array}{c}\text { World Bank, World Development Indicators } \\
\text { (https://databank.worldbank.org/data/source/world- } \\
\text { development-indicators) }\end{array}$ & $2012-2017$ \\
\hline 711 & $\begin{array}{l}\text { Trademark application class } \\
\text { count by origin }\end{array}$ & $\begin{array}{l}\text { Number of trademark applications issued to } \\
\text { residents at a given national or regional office } \\
\text { (per billion PPP\$ GDP) }\end{array}$ & $\begin{array}{l}\text { World Intellectual Property Organization, WIPO Statistics } \\
\text { Database (https://www3.wipo.int/ipstats/index.htm) }\end{array}$ & $2012-2017$ \\
\hline 712 & Industrial designs by origin & $\begin{array}{l}\text { Number of designs contained in industrial } \\
\text { design applications filled at a given national or } \\
\text { regional office (per billion PPP\$ GDP) }\end{array}$ & $\begin{array}{l}\text { World Intellectual Property Organization, WIPO Statistics } \\
\text { Database (https://www3.wipo.int/ipstats/index.htm) }\end{array}$ & $2012-2017$ \\
\hline 713 & $\begin{array}{l}\text { ICTs and business model } \\
\text { creation }\end{array}$ & $\begin{array}{c}\text { Average answer to the question: In your } \\
\text { country, to what extent do ICTs enable new } \\
\text { business models? [ } 1=\text { not at all; } 7=\text { to a great } \\
\text { extent] }\end{array}$ & $\begin{array}{l}\text { Global Innovation Index } \\
\text { (https://www.globalinnovationindex.org/analysis-indicator) }\end{array}$ & $2013-2018$ \\
\hline 714 & $\begin{array}{l}\text { ICTs and organizational model } \\
\text { creation }\end{array}$ & $\begin{array}{l}\text { Average answer to the question: In your } \\
\text { country, to what extent do ICTs enable new } \\
\text { organizational models (e.g., virtual teams, } \\
\text { remote working, telecommuting) within } \\
\text { companies? [ } 1 \text { = not at all; } 7 \text { = to a great extent] }\end{array}$ & $\begin{array}{l}\text { Global Innovation Index } \\
\text { (https://www.globalinnovationindex.org/analysis-indicator) }\end{array}$ & $2013-2018$ \\
\hline 721 & $\begin{array}{l}\text { Cultural and creative services } \\
\text { exports }\end{array}$ & $\begin{array}{l}\text { Cultural and creative services exports (\% of } \\
\text { total trade) }\end{array}$ & World Trade Organization (https://data.wto.org/) & $2012-2017$ \\
\hline 722 & $\begin{array}{l}\text { National feature films } \\
\text { produced }\end{array}$ & $\begin{array}{l}\text { Number of national feature films produced (per } \\
\text { million population } 15-69 \text { years old) }\end{array}$ & $\begin{array}{c}\text { Global Innovation Index } \\
\text { (https://www.globalinnovationindex.org/analysis-indicator) }\end{array}$ & $2013-2018$ \\
\hline 723 & $\begin{array}{l}\text { Entertainment and media } \\
\text { market }\end{array}$ & $\begin{array}{l}\text { Entertainment and media market (per } \\
\text { thousand population } 15-69 \text { years old) }\end{array}$ & $\begin{array}{c}\text { Global Innovation Index } \\
\text { (https://www.globalinnovationindex.org/analysis-indicator) }\end{array}$ & $2014-2018$ \\
\hline 724 & $\begin{array}{l}\text { Printing publications and other } \\
\text { media output }\end{array}$ & $\begin{array}{l}\text { Printing publications and other media (\% of } \\
\text { manufactures total output) }\end{array}$ & $\begin{array}{c}\text { Global Innovation Index } \\
\text { (https://www.globalinnovationindex.org/analysis-indicator) }\end{array}$ & $2013-2017$ \\
\hline 725 & Creative goods exports & Creative goods exports (\% of total trade) & $\begin{array}{c}\text { United Nations Comtrade database } \\
\text { (https://comtrade.un.org/data/) }\end{array}$ & $2012-2017$ \\
\hline 731 & $\begin{array}{l}\text { Generic top-level domains } \\
\text { (gTLDs) }\end{array}$ & $\begin{array}{l}\text { Generic top-level domains (gTLDs) (per } \\
\text { thousand population } 15-69 \text { years old) }\end{array}$ & $\begin{array}{c}\text { Global Innovation Index } \\
\text { (https://www.globalinnovationindex.org/analysis-indicator) }\end{array}$ & $2013-2018$ \\
\hline 732 & $\begin{array}{l}\text { Country-code top-level } \\
\text { domains (ccTLDs) }\end{array}$ & $\begin{array}{l}\text { Country-code top-level domains (ccTLDs) (per } \\
\text { thousand population } 15-69 \text { years old) }\end{array}$ & $\begin{array}{c}\text { Global Innovation Index } \\
\text { (https://www.globalinnovationindex.org/analysis-indicator) }\end{array}$ & $2013-2018$ \\
\hline 733 & Wikipedia monthly edits & $\begin{array}{c}\text { Wikipedia monthly page edits (per million } \\
\text { population } 15-69 \text { years old) }\end{array}$ & $\begin{array}{c}\text { Global Innovation Index } \\
\text { (https://www.globalinnovationindex.org/analysis-indicator) }\end{array}$ & $2013-2016$ \\
\hline 734 & Video uploads on YouTube & $\begin{array}{l}\text { Number of video uploads on YouTube (scaled } \\
\text { by population } 15-69 \text { years old) }\end{array}$ & $\begin{array}{c}\text { Global Innovation Index } \\
\text { (https://www.globalinnovationindex.org/analysis-indicator) }\end{array}$ & $2013-2017$ \\
\hline
\end{tabular}

Source: Own elaboration. 
Table A2. Countries in the sample

\begin{tabular}{|c|c|c|c|}
\hline Albania & Egypt & Kyrgyz Republic & Romania \\
\hline Algeria & Estonia & Latvia & Russian Federation \\
\hline Argentina & Finland & Lithuania & Saudi Arabia \\
\hline Armenia & France & Luxembourg & Senegal \\
\hline Australia & Georgia & Madagascar & Serbia \\
\hline Austria & Germany & Malaysia & Singapore \\
\hline Azerbaijan & Greece & Malta & Slovak Republic \\
\hline Bahrain & Guatemala & Mauritius & Slovenia \\
\hline Bangladesh & Hong Kong & Mexico & South Africa \\
\hline Belarus & Hungary & Moldova & Spain \\
\hline Belgium & Iceland & Mongolia & Sri Lanka \\
\hline Bolivia & India & Morocco & Sweden \\
\hline Bosnia and Herzegovina & Indonesia & Netherlands & Switzerland \\
\hline Brazil & Iran & New Zealand & Tajikistan \\
\hline Bulgaria & Ireland & Nigeria & Thailand \\
\hline Canada & Israel & North Macedonia & Tunisia \\
\hline Chile & Italy & Norway & Turkey \\
\hline China & Jamaica & Pakistan & Uganda \\
\hline Colombia & Japan & Panama & Ukraine \\
\hline Costa Rica & Jordan & Peru & United Kingdom \\
\hline Cyprus & Kazakhstan & Philippines & United States of America \\
\hline Czech Republic & Kenya & Poland & Uruguay \\
\hline Denmark & Korea, Republic of & Portugal & Vietnam \\
\hline
\end{tabular}

Source: Own elaboration. 